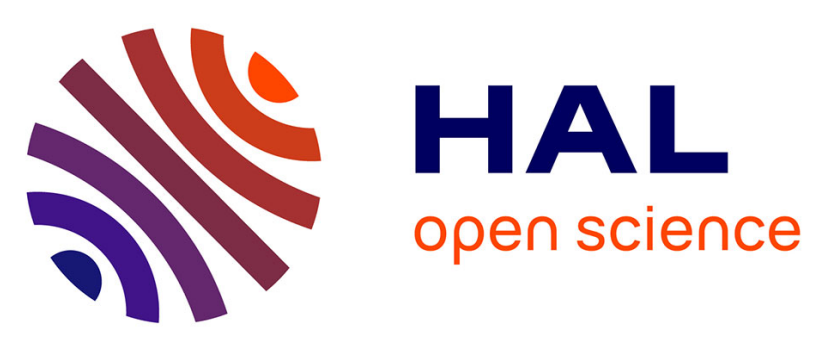

\title{
Alternative DNA repair pathways to handle complex DNA damage generated by oxidative stress and anticancer drugs
}

E. Matta, U. Aliyaskarova, A. A Kuznetsova, B. T Matkarimov, O. S Fedorova, N. A Kuznetsov, Alexander Ishchenko, M. Saparbaev

\section{To cite this version:}

E. Matta, U. Aliyaskarova, A. A Kuznetsova, B. T Matkarimov, O. S Fedorova, et al.. Alternative DNA repair pathways to handle complex DNA damage generated by oxidative stress and anticancer drugs. Miral Dizdaroglu; R Stephen Lloyd. DNA Damage, DNA Repair and Disease, 1, Royal Society of Chemistry, pp.249-278, 2020, 978-1-78801-889-0. 10.1039/9781839160769-00249 . hal-03301429

\section{HAL Id: hal-03301429 \\ https://hal.science/hal-03301429}

Submitted on 27 Jul 2021

HAL is a multi-disciplinary open access archive for the deposit and dissemination of scientific research documents, whether they are published or not. The documents may come from teaching and research institutions in France or abroad, or from public or private research centers.
L'archive ouverte pluridisciplinaire HAL, est destinée au dépôt et à la diffusion de documents scientifiques de niveau recherche, publiés ou non, émanant des établissements d'enseignement et de recherche français ou étrangers, des laboratoires publics ou privés. 


\section{Alternative DNA repair pathways to handle complex DNA damage generated by oxidative stress and anticancer drugs}

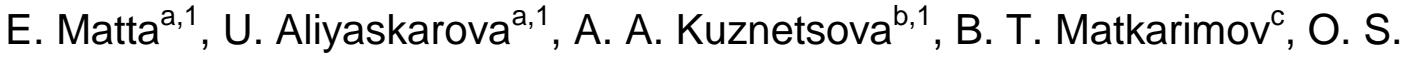
Fedorova $^{\mathrm{b}}$, N. A. Kuznetsov ${ }^{\mathrm{b}, \star}$ A. A. Ishchenko ${ }^{\mathrm{a}, \star}$ and M. Saparbaev ${ }^{\mathrm{a}, \star}$

aGroupe «Réparation de l'ADN», Equipe Labellisée LIGUE Contre le Cancer 2016, CNRS UMR9019, Université Paris-Sud, Gustave Roussy Cancer Campus, F-94805 Villejuif Cedex, France. ${ }^{\mathrm{b}}$ Institute of Chemical Biology and Fundamental Medicine, Siberian Branch of Russian Academy of Sciences, Novosibirsk 630090, Russia. 'National laboratory Astana, Nazarbayev University, Astana 010000, Kazakhstan.

*corresponding email addresses: murat.saparbaev@gustaveroussy.fr;

Nikita.Kuznetsov@niboch.nsc.ru; Alexander.ISHCHENKO@gustaveroussy.fr

${ }^{1}$ These authors contributed equally to this work. 


\section{ABSTRACT}

The clinical features of inherited human DNA repair deficient disorders such as Cockayne syndrome and Fanconi anemia point to the complex nature of endogenous oxidative DNA damage, which may include bulky adducts, inter-strand DNA crosslinks (ICLs) and clustered lesions. Conversely, severe biological effects of DNA crosslinking agents and ionizing radiation correlated with formation of ICLs and double-strand breaks in DNA, respectively. These complex DNA damages are postulated to be critical because they are more difficult to repair than singular lesions. It anticipated that the removal of ICLs and clustered oxidized bases on both strands would, if not tightly regulated, either inhibit certain steps of repair or produce persistent chromosome breaks and thus be lethal for the cells. Genetic and biochemical data indicate that the elimination of complex damages requires several distinct DNA repair pathways including: base excision repair, nucleotide incision repair, Poly(ADP-ribose) polymerases-mediated DNA strand break repair, global genome and transcription coupled nucleotide excision repair, mismatch repair, homologous recombination, non-homologous end joining, and translesion DNA synthesis pathways. In this review, we describe the role of recently discovered alternative DNA repair pathways in the removal of complex DNA lesions. 


\section{X.1 Chemical nature of complex DNA damage}

Cellular DNA constantly undergoes chemical alterations, resulting in DNA lesions that are cytotoxic, miscoding or both and are believed to be at the origin of mutagenesis and cell lethality. ${ }^{1,2}$ DNA damage can be classified by their nature:

spontaneous versus induced; by their structure: bulky versus nonbulky, base versus sugar damage, singular versus complex damage (Figure 1). Complex DNA damage (CDD) such as bulky DNA adducts, inter-strand DNA crosslinks (ICLs) and clustered lesions (including double-strand breaks, DSBs) have complex character/structure as compared to singular lesions such as randomly distributed abasic sites, deaminated, alkylated and oxidized DNA bases. 
A. Singular DNA base damage

Miscoding<smiles></smiles>

5-hydroxycytosine 7,8-dihydro-8-oxoguanine $\mathrm{C} * \mathrm{G} \Rightarrow \mathrm{T} \cdot \mathrm{A}$<smiles></smiles>

Alpha $-2^{\prime}$-deoxyadenosine<smiles>[N+]#[N+]O[C@H]1CC(O)O[C@@H]1[N+](=O)[O-]</smiles>

Regular apurinic/ apyrimidinic site<smiles>CC(C)(O)C1(C)NC(=O)NC(=O)N1</smiles>

Thymine glycol
B. Complex DNA damage

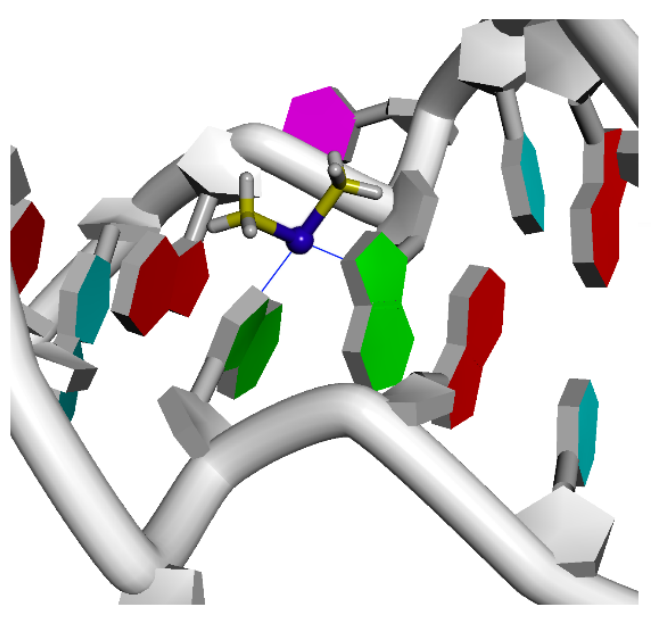

Covalent structure of a cisplatin interstrand crosslink at the GC:GC site<smiles></smiles>

7-(deoxyadenosin- $N^{6}$-yl) aristolactam II (dA-AL)

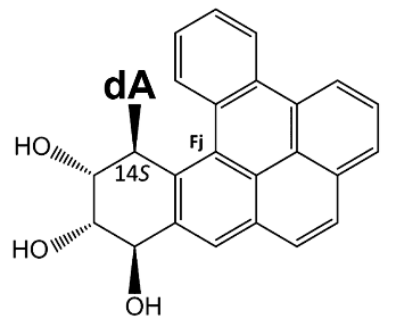<smiles>Nc1ncnc2c1nc1n2C2CC(O)C1OC2O</smiles>

(5'S)-8,5'-cyclo2 '-deoxyadenosine $(S$-cdA $)$

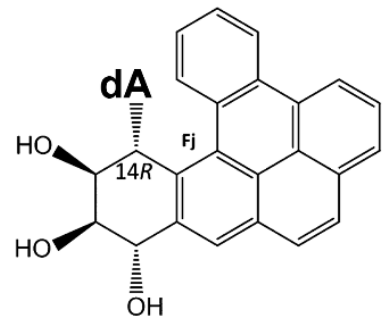

Stereoisomeric $S$ - and $R$-trans-anti-dibenzo $|a, l|$ pyrene $(\mathrm{DB}[a, l] \mathrm{P})-N^{6}$-deoxyadenosine adducts $\left(\mathrm{DB}[a, l] \mathrm{P}-N^{6}-\mathrm{dA}\right)$

Figure 1. Schematic presentation of singular and complex DNA damage. (A)

Chemical structures of some singular non-bulky DNA base lesions. (B) Chemical structures of complex DNA lesions including cisplatin-ICL and bulky repair-resistant DNA base lesions.

Two of the most important features of CDD are their bulky character and presence of more than one modification within one turn of DNA helix. Although CDD, such as ICLs and DSBs, typically constitute relatively small fraction of the total DNA damage induced by DNA crosslinking agents and ionizing radiation, respectively, they are 
expected to play disproportionately important biological roles, since if not repaired, these CDD could lead to a number of serious consequences, such as gross chromosomal rearrangements and genome instability.

\section{X.1.2. Repair-resistant bulky DNA adducts}

\section{X.1.2.1. 8,5'-Cyclopurine-2'-deoxynucleosides}

Reactive oxygen species (ROS), produced during oxidative cellular metabolism and by ionizing radiation, damage cellular DNA leading to formation of CDD. Bulky DNA adducts such as diastereoisomeric ( $\left.5^{\prime} S\right)$ - and (5'R)-8,5'-cyclo-2'-deoxyadenosine (cdA) and 8,5'-cyclo-2'-deoxyguanosine (cdG) are generated by hydroxyl radical attack at $\mathrm{C}^{\prime}$ ' sugar by $\mathrm{H}$-abstraction resulting in the formation of a covalent bond between the C5'- and C8-positions of the purine nucleoside ${ }^{3}$ (Figure 1B). These DNA adducts are helix-distorting lesions and strong blocks for both DNA replication and transcription. ${ }^{4,5}$ It was demonstrated that the global genome nucleotide excision repair (GG-NER) pathway can remove cdA adducts with an efficiency comparable to that of UV-induced cyclobutane pyrimidine dimers, but exhibits higher activity in excising the $R$-isomer. ${ }^{4,6}$ Indeed, cdG and cdA adducts accumulate in keratinocytes from NER-deficient xeroderma pigmentosum (XP) complementation group C (XPC) and Cockayne syndrome (CS) complementation group A (CSA) patients exposed to $\mathrm{X}$-rays and potassium bromate $\left(\mathrm{KBrO}_{3}\right)^{7,8}$ and also in organs of $\mathrm{CSB}^{-/-}$knockout mice. ${ }^{9}$ Noteworthy, cdA and cdG lesions accumulate in age dependent manner in nuclear DNA of wild-type mice, implying the difficulties in the removal of these complex DNA lesions. ${ }^{10}$ Also, the $S$-cdA diastereoisomer present at higher levels in organs from control non-exposed mice because they are removed by GG-NER much less efficiently than the corresponding the $R$-cdA diastereomer. ${ }^{10,11}$ 


\section{X.1.2.2. Bulky DNA adducts induced by environmental carcinogens}

Bulky DNA adducts that are generated by exposure to environmental carcinogens cause mutations that can drive malignant transformation of affected cells. As we described above, bulky DNA adducts are removed in the GG-NER pathway; however, certain bulky lesions that cause a minimal decrease, or an enhancement in the stabilities of the DNA duplex, can be very resistant to the repair machinery. Benzo[a]pyrene $(\mathrm{B}[\mathrm{a}] \mathrm{P})$ is a polycyclic aromatic hydrocarbon $(\mathrm{PAH})$ and well known carcinogen, which upon metabolic activation to diol epoxide can interact with guanines in DNA to form bulky B[a]P- $N^{2}-\mathrm{dG}$ adducts. In contrast, dibenzo[a,Ipyrene $(\mathrm{DB}[a,] \mathrm{P})$, another $\mathrm{PAH}$ that is present in about ten-fold lower concentration in the environment, is 100 times more tumorigenic than $\mathrm{B}[\mathrm{a}] \mathrm{P}$ in rodent model systems. ${ }^{12-17}$ The reactive diol epoxide intermediates of $\mathrm{DB}[a,] \mathrm{P}$ react with either $N^{6}$-adenine or $N^{2}$-guanine in DNA to form stable DB[a,JP- $N^{6}-\mathrm{dA}$ and $\mathrm{DB}\left[a, \mathrm{IP}-N^{2}-\mathrm{dG}\right.$ adducts ${ }^{18-20}$ (Figure 1B). Remarkably, Kropachev et al., demonstrated that the $S$ and $R$ diastereoisomers of DB[a,IP- $N^{2}-\mathrm{dG}$ adduct are 15 and 35 times more efficiently removed by GG-NER, respectively, as compared to the stereochemically identical $\mathrm{DB}\left[\mathrm{a}, \mathrm{J} \mathrm{P}-N^{6}-\mathrm{dA}\right.$ adducts. ${ }^{21}$ This observation suggests that the higher genotoxic activity of $\mathrm{DB}[a,] \mathrm{P}$, as compared to $\mathrm{B}[a] \mathrm{P}$, might be due to the generation of repairresistant and thus persistent $\mathrm{DB}[\mathrm{a}, \mathrm{JP}$-derived adenine adducts in exposed cells.

Other bulky DNA lesions, that cause little or no distortion and small thermodynamic destabilization of DNA duplex, also exhibit NER resistance including aristolactam-DNA adducts generated by the exposure to aristolochic acid ${ }^{22,23}$ (Figure 1B), 2-acetylaminofluorene AAF- $N^{2}$-dG adduct, ${ }^{24,25}$ 3-benzanthrone derived DNA adducts, ${ }^{26}$ and stable Fapy-dG adducts derived from aflatoxin $\mathrm{B} 1 .{ }^{27}$ Thus, despite their bulky character, certain highly mutagenic DNA lesions can escape DNA 
damage surveillance and repair. These repair-resistant DNA damage present a challenge for the cell since their can persist in the genome and lead to the transcription and replication blockages and mutations.

\section{X.1.3. Formation and chemical nature of DNA crosslinks}

Bifunctional alkylating agents, such as nitrogen mustard (HN2), psoralen and mitomycin $\mathrm{C}(\mathrm{MMC})$, can generate a covalent bond between nucleotides on opposite strands of a DNA duplex resulting in formation of ICLs. ICLs are highly lethal DNA lesions that block DNA replication, transcription and recombination by preventing strand separation. Due to their high cytotoxicity, ICL-inducing agents are widely used against hyperplastic diseases, such as cancer and psoriasis. 8-methoxypsoralen (8MOP) is a planar, tricyclic compound that intercalates into DNA duplex preferentially at 5'-TpA sites. Upon photoactivation, 8-MOP primarily photoalkylates DNA by cycloaddition to the 5,6-double bond of a thymine generating monoadducts (MA) and ICLs. ${ }^{28,29}$ Although, the yield of psoralen MAs to pyrimidine bases is three-fold higher than that of ICLs, the latter class of damage appears to have more severe biological effect. ${ }^{30}$ Derivatives of HN2 induce a variety of DNA lesions, and only $5 \%$ among them constitute cross-links between the N7 position of guanine bases on opposite DNA strands. ${ }^{31}$ The platinum compounds such as cis-diamminedichloroplatinum (II), also known as cisplatin, reacts with guanines and induces mainly DNA diadducts: $65 \% \mathrm{~d}(\mathrm{GpG})$ intra-strand cross-links, 25\% d(ApG) intra-strand cross-links and 5-8\% ICLs between the guanines in the sequence $d(G p C)$. The structures of HN2 and cisplatin-induced ICLs revealed that these agents induce dramatic distortions to the DNA helix, ${ }^{32}$ whereas MMC and psoralen-induced ICLs cause relatively minor distortions. ${ }^{33}$ Endogenous sources such as aldehydes formed as products of lipid peroxidation and nitrous acid can also form ICLs in non-treated cells. ${ }^{34}$ In addition to 
ICLs, formaldehyde, ionizing and UV radiations can crosslink proteins to an undisrupted DNA strand generating a DNA-protein crosslink (DPC). ${ }^{35}$

\section{2 DNA glycosylase-mediated repair of complex DNA lesions}

\section{2. 1. DNA glycosylase-mediated removal of bulky DNA lesions}

Bulky DNA adducts and ICLs are highly toxic for cells and accumulation of

endogenously occurring ICLs have been linked to premature aging. ${ }^{36,37}$ Although the GG-NER pathway is thought to be main pathway for the removal of ICLs and bulky lesions that disrupt DNA helix conformation, ${ }^{38,39}$ most of singular DNA lesions generated by oxidative stress are eliminated by two distinct pathways: base excision and nucleotide incision repair (BER) and (NIR), respectively. ${ }^{40,41}$

BER is initiated by a DNA glycosylase that recognizes and excises damaged bases by hydrolysis of the glycosidic bond. In general, substrate specificities of DNA glycosylases and AP endonucleases are limited to structurally small non-bulky DNA base damage that have little impact on thermodynamic stability of DNA duplex. Majority of DNA glycosylases bind to damaged DNA and flip out of the duplex the aberrant nucleotide into the enzyme's active site pocket, while inserting residues in the void left in the helix to stabilize the DNA substrate conformation. ${ }^{42-44}$ In general, nucleobase binding pockets are too small to accommodate large size DNA adducts and ICLs; however, several lines of evidence argue that DNA glycosylases are able to accommodate bulky DNA adducts despite steric constraints to fit these lesions into their active sites. Specifically, it was demonstrated that DNA glycosylases Fpg, T4 endonuclease V (T4 pyrimidine dimer glycosylase) and NEIL1 can recognize and efficiently excise very bulky DNA adducts such as imidazole ring opened form of guanine-C8-N-hydroxy-2-aminofluorene adduct, cyclobutane dimer, psoralen- 
thymine monoadduct, and aflatoxin-Fapy-guanine adducts ( $\mathrm{AFB}_{1}$-FapyGua), respectively. ${ }^{45-48}$ Structural studies revealed that T4 endonuclease V kinks the DNA helix by about $60^{\circ}$ and flips out the opposing adenine base complementary to the $5^{\prime}$ pyrimidine of the thymine dimer out of the DNA base stack, thus avoiding steric problems. ${ }^{46}$ Whereas, Fpg flips bulky N7-substituted Fapy-dG derivatives guanine lesion out of the DNA helix to the binding pocket, but enables N7-bulky group to stay outside. ${ }^{49}$ This latter mechanism might be also employed by human NEIL1 DNA glycosylase when acting upon large voluminous DNA lesions such as psoralenthymine, protein-DNA crosslinks and AFB $_{1}$-FapyGua. ${ }^{47,48,50}$

Recent studies by Eichmann laboratory revealed a new family of DNA glycosylases, which utilizes a non-base-flipping mechanism to recognize bulky DNA base damage and a certain type of ICL. ${ }^{51-53}$ DNA glycosylases AlkC and AlkD originally discovered in Bacillus cereus ${ }^{54}$ and constituting a distinct DNA glycosylases superfamily ${ }^{55}$ can excise positively charged $\mathrm{N}^{3}$ - and N7-alkylpurines with high specificity without inserting a damaged base into active site pocket. ${ }^{51}$ AlkD traps damaged bases in a sheared, base-stacked conformation, directly contacting the deoxyribose with catalytic active site residues, but not the nucleobase like other DNA glycosylases. AlkD is capable of excising bulky DNA adducts such as pyridyloxobutyl (POB) adducts, arising in DNA as a result of cigarette-smoke carcinogen - nitrosamine ketone, and N3-yatakemycinyladenine (YTMA) produced by extremely cytotoxic alkylating product yatakemycin (YTM).$^{51,56,57}$ The ability of AlkD to resolve bulky YTM and POB DNA modifications located in any grooves is presumed to be due to the absence of steric restraint. Nevertheless, the presence of other classic alkylpurine DNA glycosylases in these bacteria points to the fact that catalytic activity of AlkD is limited to positively charged DNA lesions that can be 
easily removed naturally. ${ }^{51,58}$ AlkC DNA glycosylase contains immunoglobulin (lg)like domain that was not found in the known repair proteins, which along with HEATlike repeats (HLR), allows the enzyme to almost completely wrap around DNA duplex and excise damaged nucleobases. AlkC acts through non-base-flipping mechanism similar to AlkD; however, it generates sharp kink in DNA duplex to gain access to the modified base through inserting its catalytic residues into the exposed space. $^{55}$

Azinomycin $B(A Z B)$ is a genotoxic non-ribosomal peptide-polyketide secondary metabolite produced by soil-dwelling bacteria including Streptomyces sahachiroi and Streptomyces griseofuscus. AZB generates ICLs in DNA duplexes at 5'-GNC or 5'-GNT sequence contexts by nucleophilic addition at the N7 positions of purines in a major groove. ${ }^{59}$ The classical repair mechanisms used to resolve ICLs in bacterial cells consists of coordinated function of NER machinery and homologous recombination $(\mathrm{HR}) .{ }^{60}$ Nevertheless, recently it has been found that AlkZ DNA glycosylase of Streptomyces sahachiroi is capable of unhooking AZB-induced ICLs through the cleavage of $\mathrm{N}$-glycosidic bond on both sides of the complementary DNA strands. ${ }^{58,61,62}$ The existence of unusual alternative DNA repair mechanisms in toxinproducing cells may provide insight for potential mechanisms implicated in drug resistance in cancer cells. ${ }^{53}$

\section{2. 2. DNA glycosylases mediated repair of inter-strand DNA crosslinks}

Genetic and biochemical evidences suggest that in vertebrates, the repair of ICLs proceeds in DNA replication-dependent manner and coordinated by Fanconi anemia (FA) proteins. The removal of an ICL goes through formation of a DSB as a result of the unhooking via dual incisions on both sides of the lesion by the scaffolding protein 
SLX4 and structure-specific endonuclease XPF/ERCC1. ${ }^{63,64}$ The resulting unhooked ICL is processed by translesion synthesis (TLS) specific DNA polymerases yielding a three-stranded DNA repair intermediate composed of a short oligomer covalently bound to the duplex. It thought that this crosslinked fragment or unhooked ICL is removed by the classic GG-NER pathway. ${ }^{38,39}$ However, Couve et al., revealed that the oxidative DNA glycosylases Escherichia coli (E. coli) Nei and human NEIL1 excise with high efficiency the psoralen-induced bulky unhooked ICL fragment within a three-stranded DNA structure ${ }^{65}$ (Figure 2A). Three Nei-like (NEIL) DNA glycosylases are present in mammalian cells; these proteins show structural homology to the Fpg and Nei proteins of E. coli and remove oxidised bases from DNA. ${ }^{66}$ While NEIL1 and NEIL3 appear to be cell cycle regulated, with expression peaking in S phase and late S/G2 respectively, NEIL2 is constitutively expressed throughout the cell cycle. ${ }^{67,68}$ All three proteins have DNA glycosylase and $\beta$ or $\beta / \delta$ lyase activities, with an unusual preference for single-stranded DNA and other DNA open structures generated during DNA replication and transcription.

A

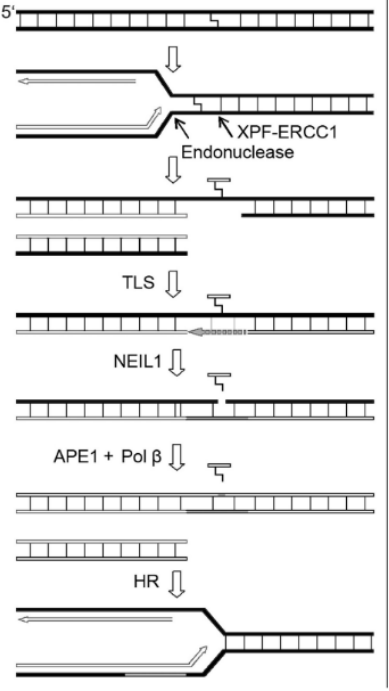

B

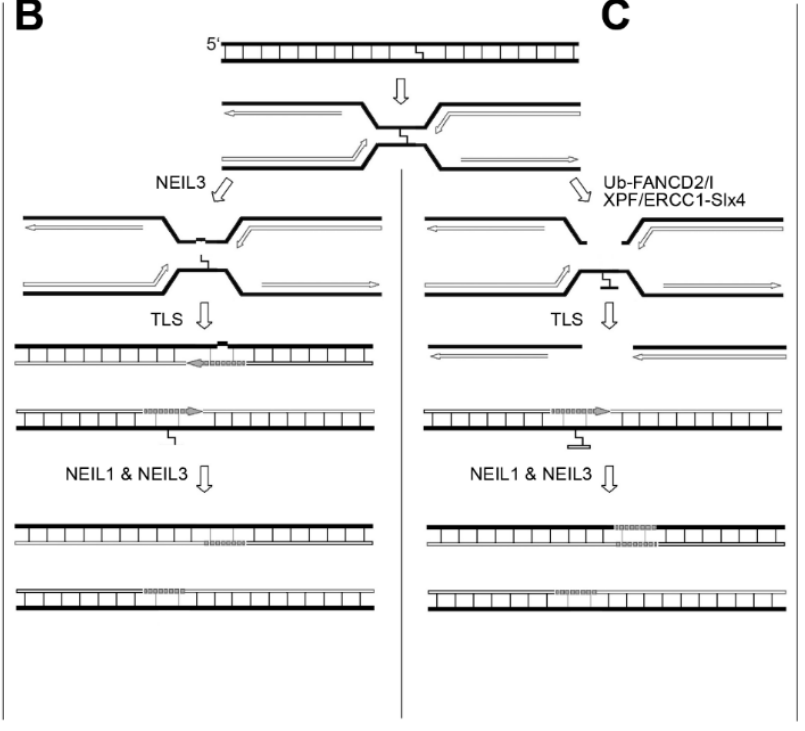

D

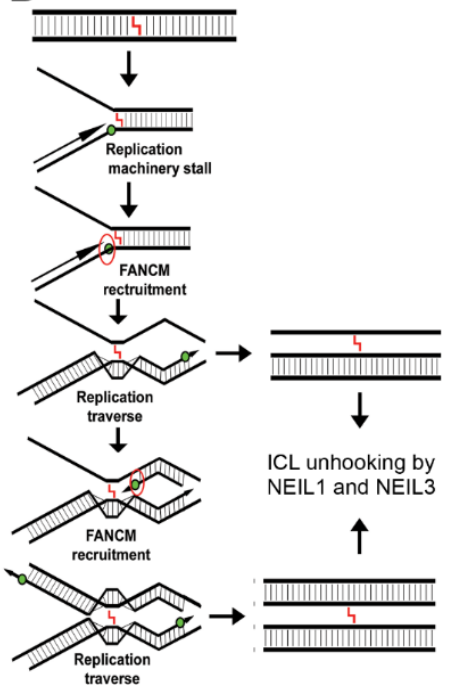


Figure 2. DNA replication-coupled repair of inter-strand DNA crosslinks. (A) NEIL1 excises unhooked crosslinked oligomer in three-stranded DNA repair intermediate. (B) NEIL3- and (C) Fanconi anemia-mediated repair of ICL. (D) The hypothetical mechanism of the FANCM-mediated DNA replication fork bypass of ICL and NEILsmediated repair of three- and four stranded crosslinked DNA structures.

Reconstitution of the repair of plasmids containing a single ICL in Xenopus eggs extracts showed that the removal of ICL was coupled to DNA replication and involved convergence of two replication forks on the lesion, with the formation of an X-shaped DNA structure ${ }^{69}$ (Figure 2B). Subsequently, it has been proposed that ICL repair requires the convergence of two forks on the lesion since, when only one fork was stalled at the ICL in egg extracts, no ICL repair took place. ${ }^{70}$ On the other side, Huang et al., investigated the collision of replication forks with fluorescently labelled psoralen-ICLs in mammalian cells using DNA combing. ${ }^{71}$ They observed that during S phase the majority of psoralen ICLs (around 60\%) were processed through a replication-traverse pathway, in which the ICLs are left unrepaired, but traversed by the replication machinery to allow DNA synthesis to resume on the other side. In these scenarios of fork traverse and the former one of dual fork convergence, a similar X-shaped DNA structure is generated around the ICL, which is critical to initiate ICL repair. ${ }^{72}$ Noteworthy, these unrepaired psoralen-induced ICLs are subsequently removed during a post-replication repair without the generation of DSBs. ${ }^{71}$ In the following work, Semlow et al., have demonstrated that NEIL3 from Xenopus laevis can excise psoralen and abasic site ICLs in DNA in X-shaped double-stranded DNA structures via an incision-independent repair mechanism, suggesting that this activity may be a principal role of NEIL3 in rapidly dividing cells ${ }^{73}$ 
(Figure 2B). More recent biochemical studies by Martin et al., showed that human NEIL3 cleaves psoralen-induced ICL in single-stranded, three-stranded and fourstranded DNA substrates to generate unhooked DNA fragments containing either an abasic site or a psoralen-thymine monoadduct. In addition, Nei and NEIL1 also excised a psoralen-induced four-stranded DNA substrate to generate two unhooked DNA duplexes with a nick, while NEIL3 targeted both DNA strands in the ICL substrate without generating single-strand breaks. Based on these observations, Martin et al., proposed a model for the mechanism of ICL repair in mammalian cells that implicates the FANCM-catalysed replication traverse of an ICL site, without preceding DNA incision and the generation of either three- or four-stranded DNA structures composed of the duplex cross-linked either to single-stranded or duplex DNA $^{74}$ (Figure 2 C). These putative ICL lesion bypass products can then be repaired by the Nei-like DNA glycosylases-initiated BER pathway without generation of highly toxic DSB (Figure 2C).

Thus, the ICL repair in eukaryotic cells is coupled to DNA replication and proceeds via two alternative mechanisms: (I) Fanconi anemia system incisiondependent pathway, which engenders replication fork collapse and generation of DSBs; and, (ii) the incision-independent pathway in which NEIL1 and NEIL3 DNA glycosylases mediate ICL unhooking without formation of highly genotoxic DNA repair intermediates. Although, an ICL covalently links the two strands of the DNA, it is important to highlight that the level of distortion of the DNA helix and the choice of the DNA repair pathway depends on the chemical nature of ICL. Cisplatin- and nitrogen mustard-generated ICLs are preferentially processed via the incisiondependent Fanconi anemia coordinated network, ${ }^{39,69}$ whereas, psoralen and abasic site induced ICLs processed rather via NEIL3-catalyzed BER pathway. ${ }^{73,74}$ 
Nonetheless, NEIL $3^{-/}$knockout mouse embryonic fibroblasts (MEF) exhibit modest sensitivity to cisplatin, ${ }^{75}$ implying that some cisplatin-ICLs might be removed in the BER pathway, which can serve as a back-up repair system for FA and NER. Importantly, it has been proposed that NEIL3-mediated repair of ICLs would be more mutagenic as compared to that of Fanconi anemia. ${ }^{73}$

\section{2. 3. Aberrant repair of interstrand DNA crosslinks}

Cisplatin [cis-diamminedichloroplatinum(II)] is well known for its capacity to trigger a strong DNA damage response signal, which may eventually result in irreversible apoptosis. Studies of the roles of BER enzymes in the repair of ICLs have produced conflicting results, suggesting involvement of multiple pathways and mechanisms depending on the cellular and structural contexts. For example, Kothandapani et al., have shown that inhibition of BER by methoxyamine (MX), a specific inhibitor of APE1-catalyzed cleavage of AP sites, along with the depletion of DNA polymerase $\beta$ $(P o \mid \beta)$ and uracil-DNA glycosylase (UNG) enhances the resistance of cells to cisplatin. ${ }^{76}$ Using synthetic oligonucleotides with a single site-specific cisplatin-ICL, the authors demonstrated that the accelerated and preferential deamination of flipped out cytosine residues next to cross-linked guanines, can induce formation of uracil residues adjacent to ICL. These uracils are excised by UNG to generate AP sites, which then are cleaved by APE1, with following Polß-catalyzed gap-filling DNA repair synthesis. The authors proposed that initiation of BER adjacent to cisplatin ICL sites could interfere with the NER and HR pathways and lead to the inhibition of ICL removal and increasing cisplatin cytotoxicity. Both repair and redox domains of APE1 appear to require for mediating cisplatin toxicity in breast cancer. ${ }^{77}$ Several small inhibitors developed against APE1, Pol $\beta$ and PARP1 are currently studying in anticancer therapy [see (see Chapters X,X,X (Kelley, Curtin, Madhusudan))]. Thus, 
understanding the roles of BER proteins in the repair of complex DNA lesions might be important to counteract the resistance of cancer cells. ${ }^{78}$

\section{X.3. The apurinic/apyrimidinic (AP) endonuclease-initiated nucleotide incision repair pathway for oxidative DNA damage}

\section{X.3.1. Substrate specificity of AP endonucleases as multifunctional enzymes}

Recognition and removal of non-bulky damage of nitrogenous bases proceed via the BER pathway initiated by DNA glycosylases. ${ }^{79-81}$ In general, the BER pathway includes sequential actions of two enzymes for DNA incision: a DNA glycosylase and an AP endonuclease (Figure 3, pathways 1-3). Noteworthy, DNA glycosylases generate highly genotoxic intermediates in DNA, e.g. AP-sites and blocking 3 '-end groups, which should be removed in order to initiate the DNA repair synthesis and ligation. AP endonucleases are key participants in the BER process, since all three types of products generated by DNA glycosylases ${ }^{82,83}$ are repaired by these enzymes. An AP endonuclease hydrolyses the phosphodiester bond located $5^{\prime}$ to the AP-site and introduces a break into the deoxyribophosphate backbone (Figure 3, pathway 1), in addition, it removes the remaining 3 '-blocking groups: either the 3' phospho $\alpha, \beta$-unsaturated aldehyde (Figure 3, pathway 2 ) or the 3 '-terminal phosphate group (Figure 3, pathway 3). 


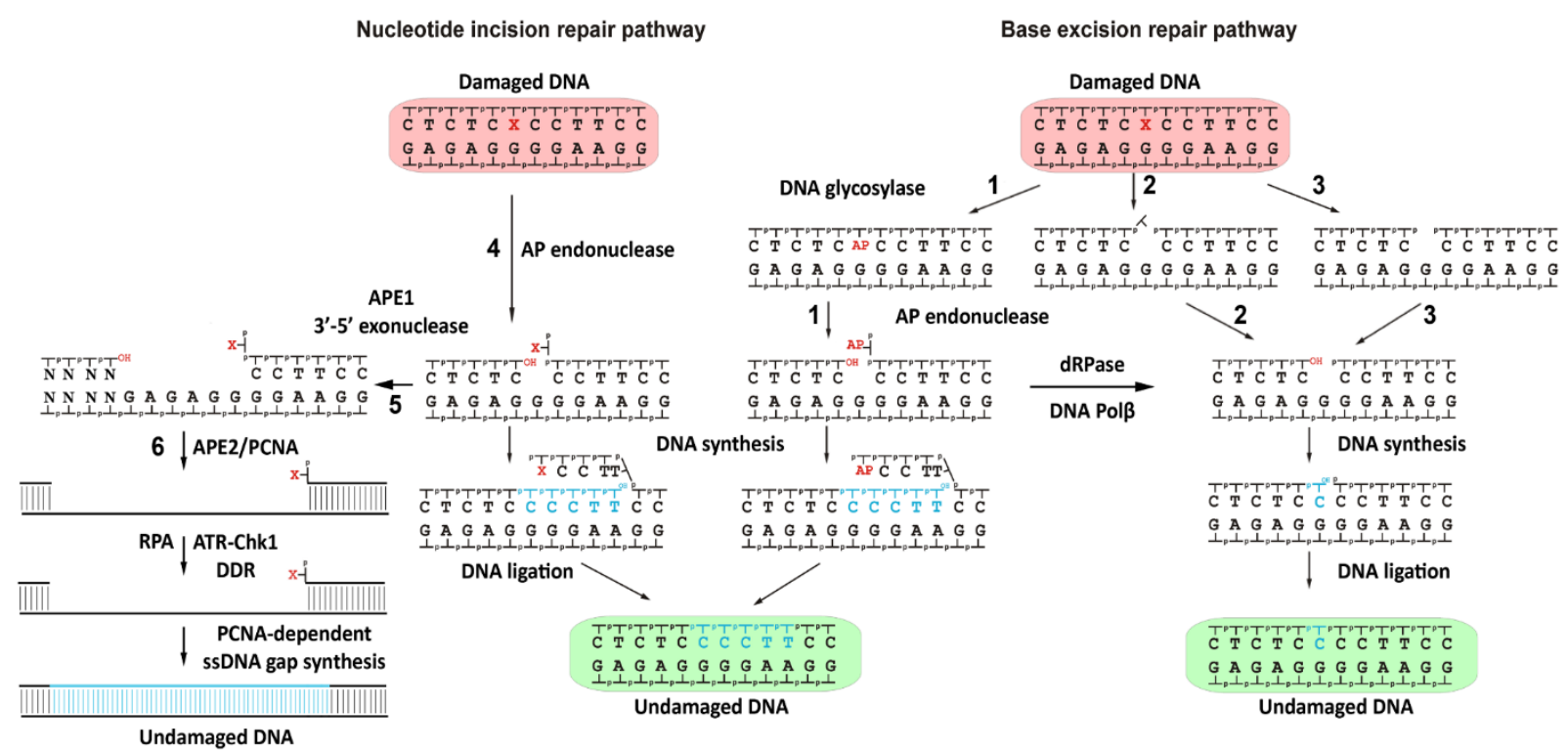

Figure 3. The scheme of BER and NIR pathways.

Previously, it was thought that the main biological function of AP endonucleases was the hydrolytic cleavage $5^{\prime}$ at AP-site and subsequent formation of SSB with a $5^{\prime}$ deoxyribophosphate and a 3'-hydroxyl group. ${ }^{84,85}$ However, certain AP endonucleases can recognise not only AP-sites, but also damaged nucleotides containing a modified base (Figure 3, pathway 4). ${ }^{86}$ This DNA glycosylaseindependent removal of damaged bases was named the NIR pathway. ${ }^{41}$ Afterwards, a number of studies have shown that AP endonucleases recognise a variety of structurally diverse types of lesions from bulky benzene-derived DNA adducts ${ }^{87}$ up to small oxidatively damaged pyrimidines. ${ }^{88}$ Noteworthy, the genetic dissection of BER and NIR functions of an AP endonuclease revealed that the NIR pathway is essential for protecting cells from potentially lethal oxidative DNA lesions, which cannot be removed by BER. ${ }^{89}$

A comparison of amino acid sequences among AP endonucleases suggests that there are two structural families, judging by similarities to two prokaryotic enzymes: 
exonuclease III (Exo III, also referred as Xth) ${ }^{90}$ and endonuclease IV (Endo IV, also referred as Nfo). ${ }^{91}$ Mammalian cells possess two AP endonucleases (APE1 and APE2) that are homologues of the bacterial Xth protein. ${ }^{92-94}$ APE1 contains a highly efficient AP endonuclease activity; however, its $3^{\prime}$-end cleansing including $3^{\prime} \rightarrow 5^{\prime}$ exonuclease activities is substantially lower than that of Xth. ${ }^{84,93,95-98}$ In addition to AP-sites, APE1 recognises a variety of damaged DNA bases, including a-anomers of 2'-deoxynucleosides ( $\alpha \mathrm{A}, \alpha \mathrm{C}$ and $\alpha \mathrm{T}),{ }^{99}$ oxidized pyrimidines, ${ }^{88}$ and uracil. ${ }^{100}$ Contrary to APE1, the $3^{\prime} \rightarrow 5^{\prime}$ exonuclease activity of APE2 is higher than its AP endonuclease activity and may represent the main biological function of this enzyme. ${ }^{101}$ Of note, several other Xth-like AP endonucleases such as prokaryotic enzymes (Mycobacterium tuberculosis MtbXthA and Neisseria meningitides NApe and NExo) and a plant enzyme (Arabidopsis thaliana atAPE1L) lack the NIR function. ${ }^{102-104}$

Furthermore, recently, a novel AP endonuclease, referred as endonuclease $Q$ (EndoQ), which does not belong to Xth and Nfo-family, was identified in the hyperthermophilic euryarchaeon Pyrococcus furiosus. EndoQ is involved in the NIR pathway for uracil and hypoxanthine residues in DNA. ${ }^{105,106}$ Noteworthy, amino acid sequence analysis indicates that putative EndoQ homologs are present in most of Archaea, but only in a few groups in bacteria. ${ }^{105} \mathrm{~A}$ homolog of EndoQ in the grampositive bacterium Bacillus pumilus, exhibits NIR activity towards uracil residues. ${ }^{107}$ EndoQ enzymes generate a nick immediately $5^{\prime}$ to uracil, hypoxanthine, xanthine, and AP site in DNA. ${ }^{105,107}$ Notably, the endonuclease activity of $P$. furiosus EndoQ towards a uracil is identical to that of E. coli Xth acting upon AP-site. ${ }^{106}$ 
It should be noted that the same catalytic mechanism of $5^{\prime}$-phosphodiester bond hydrolysis was proposed for members of both the Xth family ${ }^{92,108-111}$ and Nfo family enzymes. ${ }^{91,112,113}$ Despite differences in the structure and metal requirements among these AP endonucleases, a comparison of their active-site structures surprisingly reveals strong geometric conservation of the catalytic reaction. ${ }^{114,115}$ Nonetheless, there is still a debate in the literature about the functional role of certain amino acid residues in the active site of enzyme. ${ }^{116-119}$ In addition, it has been shown that during the endoribonuclease action of human APE1, the $\mathrm{Mg}^{2+}$ ion is not required, thus pointing to an alternative catalytic mechanism in the case of RNA substrates. ${ }^{120}$

\section{3. 2. A putative physiological role of APE1-catalyzed NIR and $3^{\prime} \rightarrow 5^{\prime}$ exonuclease functions}

Both human APE1 and its homolog APE2 contain $3^{\prime} \rightarrow 5^{\prime}$ exonuclease activity ${ }^{101,121}$ and this function is evolutionary conserved in Xth- and Nfo-families of AP endonucleases. Importantly, previous studies have established that $E$. coli Nfo and human APE1-catalyzed NIR and $3^{\prime} \rightarrow 5^{\prime}$ exonuclease activities are functionally and genetically coupled and that the repair of oxidatively damaged base in the DNA glycosylase-independent NIR pathway can generate a small single-stranded (ss) gap $5^{\prime}$ to the lesion in duplex DNA. ${ }^{88,122,123}$ On the other hand, it has been shown that Xenopus and human APE2 can exonucleolytically process single-strand DNA break (SSB) in the $3^{\prime} \rightarrow 5^{\prime}$ direction to generate an extended ssDNA gap, which in turn activates ATR-Chk1 DNA damage response (DDR) pathway. ${ }^{124,125}$ More recently, using Xenopus egg extracts Lin et al., demonstrated that APE1's exonuclease function is required for APE2-mediated 3'-resection of SSB and ATR-Chk1 signalling. ${ }^{126}$ Strikingly, Xenopus APE1-D306A mutant, which corresponds to human 
NIR-deficient APE1-D308A variant, ${ }^{123}$ is unable to trigger ATR-Chk1 DDR in egg extracts, ${ }^{126}$ implying the role of NIR function in the generation of extended SsDNA gaps at oxidized DNA bases. Taken together, these observations led us to propose a schematic model in which the removal of oxidized bases in DNA glycosylaseindependent NIR pathway generates extended ssDNA gap via coupled action of APE1 and APE2/PCNA complex (Figure 3, pathways 5-6). The resulting gapped ssDNA structure bound with RPA, triggers ATR-Chk1 DDR pathway in the replication-independent manner, which in turn enables the PCNA-directed gap filling by high-fidelity DNA polymerases (Figure 3, left panel). It is tempting to speculate that the NIR pathway may take place in actively transcribed open chromatin regions to ensure high-fidelity DNA repair synthesis, whereas, the classic BER pathway occurs in heterochromatin and proceeds mainly via DNA polymerase $\beta$-dependent short-patch pathway (Figure 3, pathways 2 and 3).

\section{3. 3. Conformational dynamics of enzyme-substrate complexes}

Despite the active research into functional features of AP endonucleases, it is currently unknown how the active site of one enzyme can recognise substantially different (by structure and by nature) damaged and undamaged nucleotides. Certain important features of catalytic complex formation are still unclear: the sequence of the enzymatic events; the nature of interactions at the initial stage of substrate recognition; formation of which contacts leads to the discrimination between a substrate and 'non-substrate'; and which interactions ensure substrate specificity of the enzyme. Therefore, a major contribution to the understanding of the mechanisms underlying specific enzyme-substrate interactions has been done in studies utilizing pre-steady-state kinetics and thermodynamics of the enzymatic process with registration of conformational transformations of the interacting molecules. 
Conformational transformations of AP endonucleases were recorded by means of a change in the intrinsic fluorescence of their tryptophan residues. ${ }^{127-132}$ In nucleic acids, conformational transitions can be detected using fluorescent analogues of heterocyclic bases. ${ }^{119,133-141}$ It has been reported that the interaction of APE1 with a substrate includes at least two stages: DNA binding and recognition of an AP-site, which result in the formation of a catalytically-competent complex. The irreversible stage of catalytic hydrolysis of the 5'-phosphodiester bond at the AP-site takes place in this complex. The last stage of the kinetic mechanism is characterised by an equilibrium process of enzymatic-complex dissociation from the reaction product. Thermodynamic analysis of the fast stages of recognition and cleavage of DNA containing an abasic site ${ }^{132}$ has shown that there are two steps, DNA binding and Fsite recognition that cause the formation of a catalytically competent complex.

\section{3. 4. The mechanism of substrate specificity towards damaged nucleotides, with human APE1 as an example}

During the last three decades, extensive characterization of DNA repair enzymes provided insight into how damaged DNA bases were located and recognised among numerous unmodified bases. ${ }^{142,143}$ Structural data indicate that conformational changes in the enzyme and DNA play an important part in the recognition of specific substrates and may control the substrate specificity of enzymes. ${ }^{144-154}$

Nevertheless, a recent report uncovered substantial differences in the mechanisms of specific substrate recognition by many well-studied DNA glycosylases and by human APE1 ${ }^{155}$ This study clarified the key steps of the mechanism underlying APE1-DNA interaction that enable high-specificity recognition of structurally different damaged DNA containing $\varepsilon A, \alpha A, 5,6$-dihydrouridine, and an F-site. Accordingly, ${ }^{155}$ 
the substrate specificity of APE1 should depend on the efficiency of damagednucleotide eversion from the duplex during enzyme-induced DNA bending. The ability of an AP site or damaged nucleotide to flip out of DNA and to penetrate the enzyme pocket during the formation of contacts between the enzyme and DNA may be the main contributing factor for substrate specificity of APE1. This conclusion means that the model of a mutual enzyme-substrate induced fit, as determined for DNA glycosylases, ${ }^{156}$ is now transformed into the model of conformational selection in the case of APE1 (Figure 4). In this model, any nucleotide, which everts from the duplex in the response to a disturbance induced by the enzyme and enters into the active site, will be a substrate for the enzyme. This model of substrate specificity is well consistent with the ability of APE1 to act as an exonuclease and endoribonuclease because of the structural features of RNA that help with the eversion of intact nucleotides at the junction of the single-stranded parts, hairpins, duplexes, and loops. Moreover, it is reasonable to propose that non-B-form DNA and some structures formed due to DNA sequence flexibility can bind to APE1 and lead to undamaged-nucleotide recognition with subsequent topology-specific DNA cleavage. 


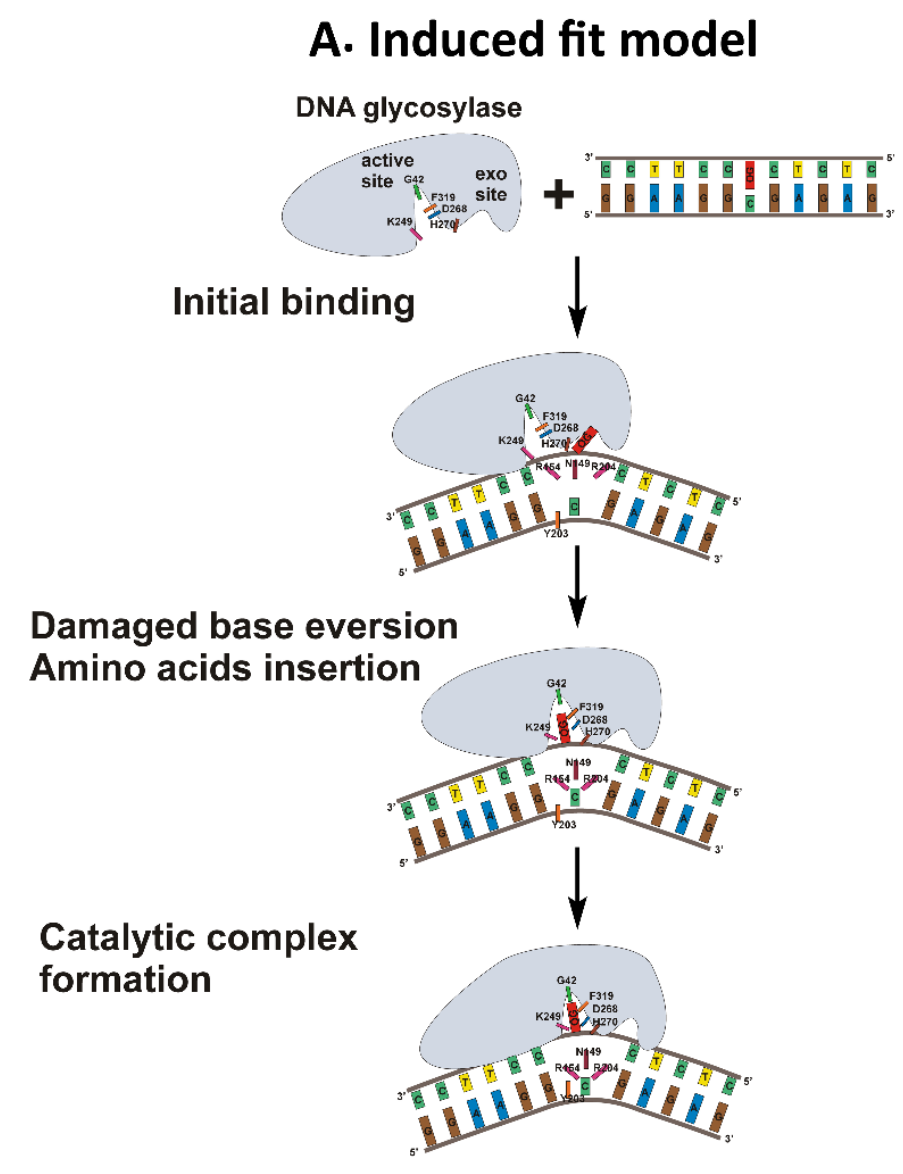

B. Conformational selection model in Damage eversion into the active site
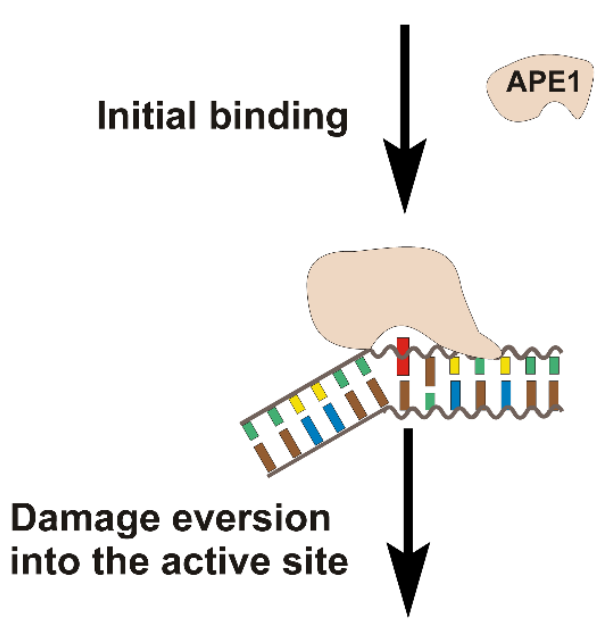

Figure 4. Mechanisms of DNA damage recognition by DNA glycosylases, ${ }^{90,104}$ (A) and AP endonucleases ${ }^{78,102}(\mathbf{B})$.

\section{4. Poly(ADP-ribose) polymerase catalysed covalent modification of DNA strand break extremities and its role in DNA repair}

Endogenous and exogenous DNA damage are rapidly sensed and activate evolutionarily-conserved signaling pathways, known collectively as DDR, whose components can be separated into four functional groups: damage sensors, signal transducers, repair effectors, and arrest or death effectors. ${ }^{157}$ Single-stranded, double-stranded and complex closely spaced clustered DNA strand breaks that represent either an initial DNA damage or DNA repair intermediates generated during DNA damage processing by cellular DNA repair enzymes are one of the 
fastest and most strong inducers of DDR. DNA break-sensing molecules, poly(ADPribose) polymerases (PARPs) are the key element of the DDR in mammalian cells. PARPs catalyze transfer of mono- or poly-ADP-ribose (MAR or PAR, respectively) moieties on proteins, ${ }^{158} \mathrm{DNA}^{159,160}$ and $\mathrm{RNA}^{161}$ by using nicotinamide adenine dinucleotide $\left(\mathrm{NAD}^{+}\right)$as a substrate. It has been shown that these post-translational, post-replicative and post-transcriptional modifications play roles not only in DNA damage repair, ${ }^{162}$ but also in a large array of cellular processes including regulation of gene expression, apoptosis and autophagy (reviewed $\mathrm{in}^{163-166}$ ).

The PAR polymer designates a chain of ADP-ribose (ADPr) units, where each unit is linked to other one through glycosidic ribose-ribose $1^{\prime \prime} \rightarrow 2^{\prime}$ bonds. ${ }^{167}$ This polymer can vary in length from a few to $200-400$ ADPr units in vivo and in vitro. ${ }^{168}$ The PAR can be branched at a frequency of 1 branch per 20-50 subunits of the linear polymer. Branched PAR polymer can have a very complex structure, including helicoidal secondary structures which are, at some extent, similar to RNA and DNA. ${ }^{169}$ PAR (free or attached to proteins) that is synthesized upon genotoxic stress may undergo biphasic decay, with most ( $85 \%)$ of PAR having a half-life of about 40 $\mathrm{s}$ and the remaining catabolized within approximately $6 \mathrm{~min}$. In contrast, the constitutive fraction of PAR have a much longer half-life $(\sim 7.7 \mathrm{~h}) .{ }^{170} \mathrm{~A}$ tight regulation of the level of the polymer in the cell by ADPr-protein hydrolases, that reverse the reaction by hydrolyzing the protein-ADPr bond or the bonds between two ADPr units of PAR is important, since its accumulation have strong cytotoxic effects. ${ }^{171}$

Family of PARPs, also known as diphtheria toxin-like ADP-ribosyltransferases includes 18 known members ${ }^{168}$ that are divided into 4 sub-families as DNA dependent PARPs, Tankyrases, CCCH PARPs and macroPARPs. ${ }^{172}$ Among PARPs only PARP1, PARP2 and PARP3 are activated in DNA dependent manner, which 
signals the presence of DNA strand breaks. ${ }^{173}$ PARP1-3 structures consist of multiple independent domains connected by flexible linkers. ${ }^{174}$ Binding and recognition of sites of DNA strand breaks induce the reorganization of PARPs domains structures, promoting extensive inter-domain contacts and allosteric activation, by unfolding of an auto-inhibitory helical domain (HD), which then allows $\mathrm{NAD}^{+}$binding necessary for ADP-ribosylation activity. ${ }^{174-177}$ PARP1 is the most ubiquitous and abundant PARP, which responsible for majority of the PARylation activity in a cell in response to DNA damage and involved in multiple DNA repair pathways, including BER, HR, NHEJ and NER. ${ }^{166,178,179}$ PARP2 plays partially redundant functions with PARP1 and accounts for about $10 \%$ of DNA damageinduced cellular PARylation activities, which are essential for cell survival. Depletion of PARP1 or PARP2 results in hypersensitivity to ionizing radiation, oxidative stress and alkylating agents, whereas double-knockout mice show early embryonic lethality. ${ }^{180}$ PARP3 is characterized by MARylation activity and act synergistically with PARP1 in response to genotoxic drugs and X-irradiation generating DSBs. ${ }^{181-183}$ Importantly, PAR attached to a protein rapidly degraded by PAR glycohydrolase (PARG), except for the last MAR moiety, which remains bound to the protein. PARG specifically hydrolyses the ribose-ribose bonds and it is the main enzyme in mammalian cells. Disruption of PARG gene in mice results in embryonic lethality and PARG-deficient cells exhibited increased cell death and impaired repair of DNA base damage and strand breaks, ${ }^{184}$ indicating that accumulation of the PARylated macromolecules is highly toxic to the cell.

The widespread presence of PARP proteins in eukaryotes and their protein modification activity are possibly due to the fact that in eukaryotic cells, DNA is tightly packed into a composite of DNA and proteins referred to as chromatin. Chromatin 
structure imposes restriction upon DNA-protein interactions, and several studies have demonstrated that tight chromatin packaging restrict the ability of DNA repair machinery to access the sites of DNA damage. ${ }^{185,186}$ PARPs mediated ADPribosylation of histones and other nuclear proteins induce recruitment and modification of chromatin remodeling factors, including chromatin insulator protein CTCF (CCCTC-binding factor) and chromodomain-helicase-DNA-binding protein 1like (ALC1), and provide an effective chromatin remodeling mechanism necessary for the recruitment of repair proteins to DNA damage sites and efficient repair of DNA strand breaks (reviewed in ${ }^{164,179,187,188}$ ). Moreover, covalently attached ADPribose polymer with a complex branched structure confers negative charge to PARPs and histones, resulting in decrease in DNA binding and electrostatic repulsion of these proteins from DNA. ${ }^{189,190}$ However, in the case of severe genotoxic stress, hyperactivation of PARP results in strong reduction of NAD+ levels, which in turn, induce release of apoptosis-inducing factor (AIF) from mitochondria and lead to apoptosis in a caspase-independent manner. ${ }^{191}$

Recently, it has been demonstrated that in vitro PARP1-3 can reversibly ADPribosylate termini of DNA molecules containing multiple closely spaced DNA strand breaks (DSB and SSB), producing a covalent PAR/MAR-DNA adducts, pointing to the underlying complex nature of the PARP-dependent DNA strand break signaling. 159,192,193. Mechanistic studies showed that PARP1 and PARP2 can covalently modify DNA duplexes by PARylation of 3'- and 5'-terminal phosphates and 2'-OH termini of modified nucleotides at DNA strand breaks. ${ }^{159}$ Contrary to ADP-ribosylation of proteins, PAR and MAR DNA modifications can be effectively and completely removed by PARG. ${ }^{159,192,193}$ MACROD2, TARG1 and ARH3 hydrolases can also remove the MAR adduct from DNA, leaving phosphorylated termini. ${ }^{193}$ PARP2 and 
PARP3 can ADP-ribosylate DNA termini in long linear and circular DNA duplexes, which more closely resemble the cellular DNA context. ${ }^{192}$ Most importantly, under certain configuration of strand breaks in duplex DNA, PARPs can switch their substrate specificity from auto-ADP-ribosylation to DNA-ADP-ribosylation. ${ }^{192}$ DNA PARylation experiments in cell-free extracts and immunoblotting experiments with purified genomic DNA after genotoxic treatment suggest that certain types of complex DNA strand breaks in chromosomal DNA can be ADP-ribosylated by PARPs in the cellular response to DNA damage. ${ }^{192}$

The three-dimensional structures of PARP1 bound to DNA with a SSB revealed that PARP1 binds and bends DNA duplex at an SSB site through cooperative interactions of two N-terminal zinc finger domains (F1 and F2) with exposed DNA bases and adjacent minor grooves and then drives stepwise assembly of the remaining F3, WGR (Trp-Gly-Arg) and catalytic (CAT) domains leading to PARP1 activation. ${ }^{174,176}$ In contrast, PARP2 and PARP3 use only short N-terminal and WGR domains for binding to damaged DNA. ${ }^{181,194}$ However, the resolved crystal structures of assembled PARP-DNA complexes still do not provide sufficient insight into the observed PARPs specificity for the phosphorylated DNA termini. In these complexes, the DNA-binding site of PARP1 is far from its catalytic (CAT) domain in activated PARP1-DNA complex and sterically protected from ADP-ribosylation by the PARP1 protein itself. However, another proximal DNA strand breakage site in the same PARP-DNA complex might interact with the CAT domain taking into account high flexibility of domain linkers. A putative mechanistic model of DNA strand breakoriented ADP-ribosylation of DNA termini by PARP1-3 shown in Figure 5 has been proposed based on the observed dependence of DNA termini covalent modification on the distance between the phosphorylated DNA terminus as an acceptor and the 
DNA strand break as an activator. ${ }^{192}$ The following rules have been established for the efficient ADP-ribosylation of $5^{\prime}$ or $3^{\prime}$ upstream DNA termini in duplex DNA containing multiple strand breaks: (i) the distance between phosphate residue and SSB should not exceed $\sim 2$ helix turns of DNA duplex; and (ii) the relative position of the acceptor phosphate on DNA helix to the DNA-bound and activated PARPs. ${ }^{192}$

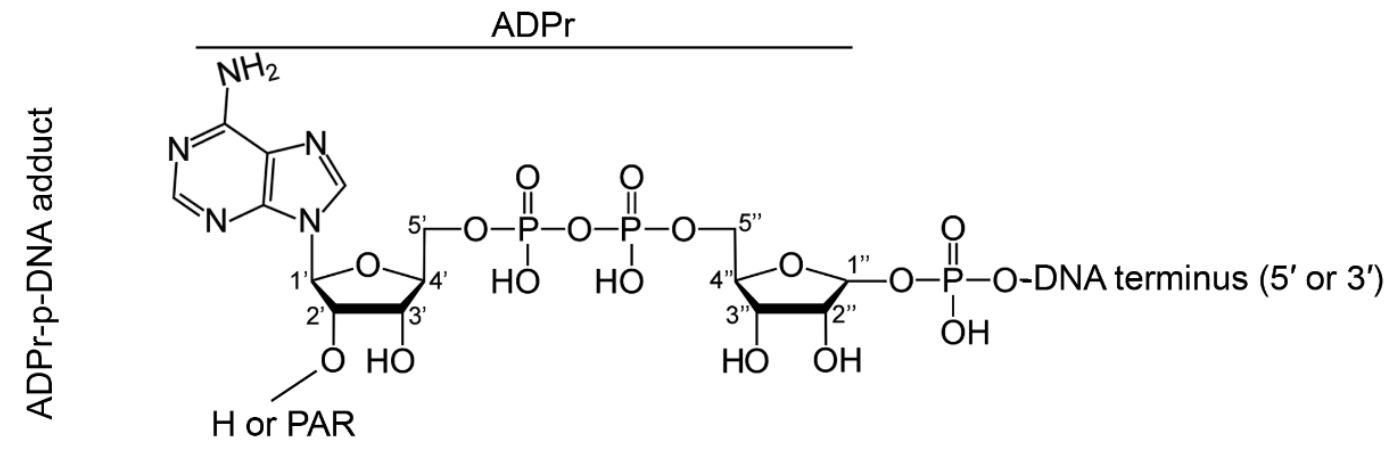

PARP2 and PARP3

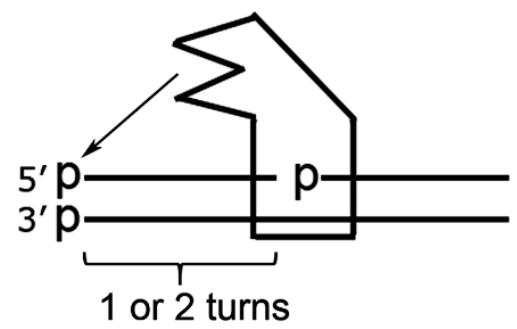

1 or 2 turns

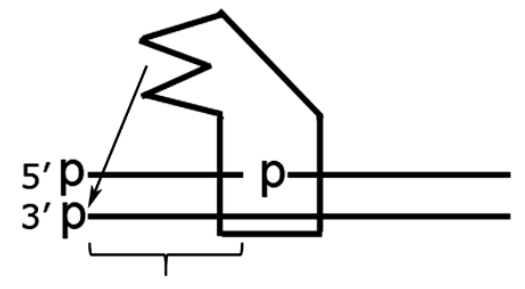

1.5 turns
PARP1

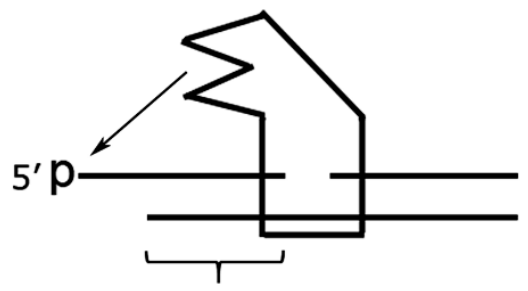

1.3 turns

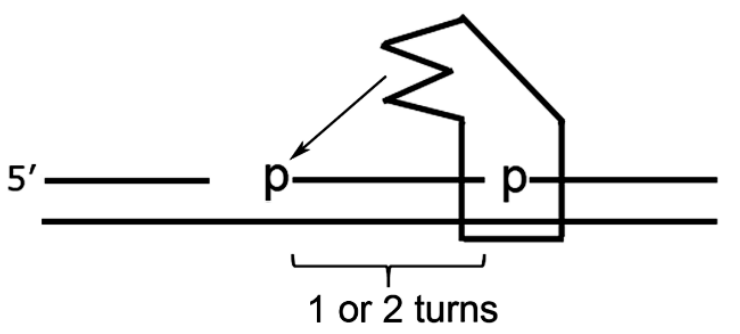

Figure 5. The mechanistic model of DNA strand break-oriented DNA termini ADPribosylation by PARP1, PARP2 and PARP3.

Specific requirements for closely spaced or clustered DNA strand breaks in the PARP-dependent DNA ADP-ribosylation open an important question: whether such 
DNA strand breaks can be formed for example by ionizing radiation, and if there are some DNA processing pathways that may generate strand breaks in a non-random manner? It is quite possible that DNA duplexes containing DSB and proximal SSB can be generated during DSB repair by HR and NHEJ repair pathways. Intriguingly, it has been found that the MRN-CtIP complex generated an internal nick located 20 nucleotides downstream of $5^{\prime}$-termini of a DSB, ${ }^{195}$ and that this configuration of closely-spaced DNA strand breaks is prone to covalent DNA ADP-ribosylation by the PARP1-3 proteins.

Importantly, not only DNA strand breaks activate PARPs catalyzed ADP-ribosylation. PARP1 can also be activated by DNA hairpins, cruciform structures, stalled replication forks, stably unpaired regions and other non-B-conformations of DNA. ${ }^{196,197}$ Thus, the presence of a single SSB or DSB near to some of non-B DNA structures or specific chromatin configurations could potentially trigger ADPribosylation of DNA strand breaks termini. Moreover, the pool of PARPs activators has been enlarged during different studies showing that PARPs can be activated independently of DNA by protein-protein interactions, post-translational modifications and by specific type of RNA structures (summarized in Table 1). ${ }^{163,172,198-200}$ In addition to PARP1 and Tankyrase, a new PARPs family member has been shown to be activated by a DNA damage independent way. During genotoxic stress, PARP2 is activated by binding to RNA via its SAP domain, in nucleoli, and this stimulates PAR formation. ${ }^{201}$ On the other hand, PARP1 inactivation was observed upon binding to the histone variant macroH2A $1.1,{ }^{202}$ also the deacetylation and sumoylation of PARP1 inhibit its self-PARylation. ${ }^{199}$ 
Table 1. Mediators of PARP1-3 activation

\begin{tabular}{|c|c|c|c|}
\hline $\begin{array}{l}\text { Type of } \\
\text { activation }\end{array}$ & Activator & $\begin{array}{l}\text { Activated } \\
\text { PARP }\end{array}$ & References \\
\hline$\frac{\text { D }}{\frac{5}{6}}$ & $\begin{array}{l}\text { non-B DNA structures (hairpins, cruciforms, } \\
\text { and loops) }\end{array}$ & PARP1 & 197,204 \\
\hline 蒠 & DNA breaks: nicks, gaps, flaps, DSB & PARP1-3 & $174-177,205,206$ \\
\hline 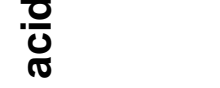 & small nucleolar RNA & PARP1 & 207 \\
\hline$\frac{\pi}{0}$ & Short rRNA and other single-stranded RNAs & PARP2 & 201 \\
\hline$\overline{\mathbf{z}}$ & PAR polymer & PARP2 & 208 \\
\hline & Nucleosomes and histones & & 209,210 \\
\hline & $\begin{array}{l}\text { Phosphorylated extracellular signal-regulated } \\
\text { kinases, ERK }\end{array}$ & & 211 \\
\hline$\frac{0}{\overline{0}}$ & $\begin{array}{l}\text { Nicotinamide mononucleotide } \\
\text { adenylyltransferase 1, NMNAT1 }\end{array}$ & PARP1 & 212 \\
\hline .․ㅡ & CTCF & & 213 \\
\hline 홈 & TET1 & & 214 \\
\hline$\stackrel{\complement}{\Phi}$ & TOPO2 & & 215 \\
\hline$\overline{0}$ & $\begin{array}{l}\text { Bromodomain adjacent to zinc finger domain } \\
2 \mathrm{~A}, \mathrm{BAZ2A} / \mathrm{TIP} 5\end{array}$ & & 216 \\
\hline & Human tyrosyl tRNA synthetase, TyrRS & & 217 \\
\hline$\frac{\bar{\sigma}}{\stackrel{0}{0}}$ & $\begin{array}{l}\text { phosphorylation at Ser372 and Thr373 } \\
\text { (by extracellular signal-regulated kinases, } \\
\text { ERK1/2) }\end{array}$ & & 218 \\
\hline & phosphorylation at Tyr907 (by c-Jun N- & & 219 \\
\hline
\end{tabular}




\begin{tabular}{|c|c|c|}
\hline terminal kinase, JNK1/ MAPK8 ) & \multirow{8}{*}{ PARP1 } & \\
\hline $\begin{array}{l}\text { phosphorylation at Ser782, Ser785, and } \\
\text { Ser786 } \\
\text { (by cyclin-dependent kinase, CDK2) }\end{array}$ & & 220 \\
\hline $\begin{array}{l}\text { acetylation at Lys498, Lys505, Lys508, } \\
\text { Lys521, and Lys524 } \\
\text { (by E1A binding protein, p300/ CREB-binding } \\
\text { protein CBP) }\end{array}$ & & 221 \\
\hline $\begin{array}{l}\text { acetylation of 1-214 and 477-525 aa regions } \\
\text { (by P300/CBP-associated factor, PCAF) }\end{array}$ & & 222 \\
\hline MARylation by PARP3 & & 223 \\
\hline MARylation at Lys 521 (by Sirtuin 6, SIRT6) & & 224 \\
\hline $\begin{array}{l}\text { phosphorylation at Thr420, Thr622, Thr656 } \\
\text { (by checkpoint kinase 2, CHK2) }\end{array}$ & & 225 \\
\hline $\begin{array}{l}\text { methylation at K508 (by Histone-lysine N- } \\
\text { methyltransferase, SET7/9) }\end{array}$ & & 226 \\
\hline
\end{tabular}

The phenomenon of ADP-ribosylation of a terminal phosphate group at the DNA strand breaks opens important question about possible functional role of this new modifying activity of PARPs. It is generally accepted that covalently attached PAR polymer confers negative charge to PARPs, histones and other PARylated proteins, resulting in decrease in DNA binding and electrostatic repulsion of these proteins from DNA. ${ }^{190}$ Thus, PARylated proteins together with PAR-recruited complexes of DNA repair factors might be also withdrawn together from the site of DNA damage. In contrast, the PAR chain covalently attached to DNA termini should stably recruit 
those factors directly to the site of DNA damage. Importantly, it has been recently demonstrated that DNA MARylated at 5'-phosphate at $1 \mathrm{nt}$ gap is recognized as $5^{\prime}$ adenylated DNA substrate and can be ligated in the absence of ATP by DNA ligase I, IIla and by other DNA ligases, producing ligated double-stranded DNA molecule with an aberrant AP site. This AP site can be further processed by BER-associated APE1. ${ }^{160}$ In line with these results, it has been suggested that PARP2 and PARP3 are involved in the final ligation step of NHEJ, because 5' phosphorylated nicks are particularly efficient activators of auto-ADP-ribosylation activity of PARP2 and PARP3, but not PARP1. We speculate that DNA ADP-ribosylation can promote retention of the DSB ends until either the full repair complex put in place or required ATP concentration for DNA ligation reached. Similarly, in the case of SSB repair PARP-mediated ADP-ribosylation can promote ligation of a gap without a polymerase synthesis and ATP. Of note, PARP-mediated extensive PAR synthesis can block the glycolysis and lead to ATP loss and the inhibition of hexokinase 1 activity. ${ }^{203}$

We hypothesize that the role of the ADP-ribosylation of DNA strand break termini is different from that of proteins (Figure 6) since it: (i) can be used as a temporary block of the processing of strand breaks and by this protect them from non-specific degradation and aberrant error-prone end joining; (ii) inhibits the NHEJ via inhibition of the binding of Ku to DSB ends; (iii) promotes direct aberrant ligation of ADPribosylated DNA breaks during bioenergetic collapse in order to avoid degradation and de novo formation of toxic DSBs; (iv) initiates and stimulates DNA strand resection by MRN complex to promote the alternative DNA repair pathways; (v) enables an efficient apoptotic signal if not removed; (vi) triggers relocation of the damaged DNA loci to the special nuclear compartments; (vii) provides precise 
PAR/MAR-guided recruitment and assembly of the DNA repair factors; and (viii) coordinates the choice of the DNA breaks signaling, processing and repair pathways.

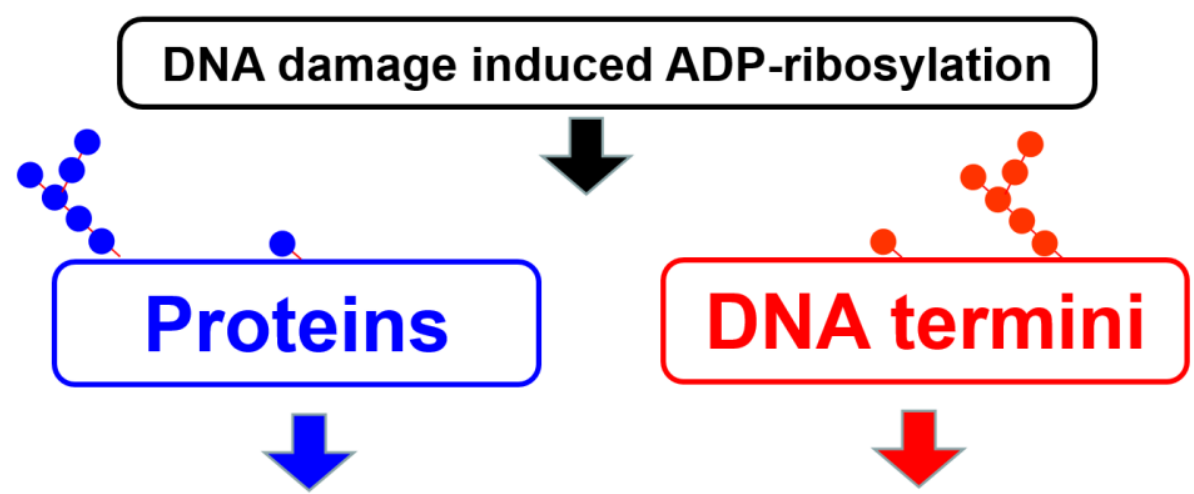

DNA damage signaling and recruitment of chromatin, transcription and DNA repair factors
CO

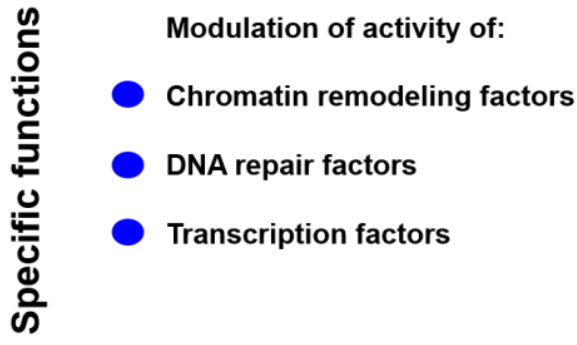

Protection from non-specific degradation of DNA termini Recruitment of specific DNA-ADP ribose adduct readers directly to DNA breaks

Inhibition of DNA breaks processing and repair in response to severe DNA damage

Saving broken DNA strands during an energy collapse caused by genotoxic stress

Trigger relocation of the damaged DNA loci to the special nuclear compartments

Figure 6. Putative and confirmed roles of the PARPs-catalyzed ADP-ribosylation in response to DNA damage.

\section{Acknowledgments}

This research was supported by grants to Murat Saparbaev from la Ligue National Contre le Cancer "Equipe Labellisee LIGUE 2016" and Electricité de France (RB 2017); to Alexander Ishchenko from French National Research Agency (ANR-18CE44-0008) and Fondation ARC (PJA-20181208015); to Alexandra Kuznetsova the 
Russian Science Foundation grant No. 19-74-10034 (substrate specificity of AP endonucleases); to Bakhyt T. Matkarimov from Nazarbayev University Oak Ridge Associated Universities (ORAU) grant 091019CRP2111. E.M. and U.A. were supported by doctoral fellowships from ABELA FRERES and from MESR (Ministère de l'Enseignement Supérieur et de la Recherche), respectively.

\section{References}

1. T. Lindahl, Nature, 1993, 362, 709.

2. J. A. Imlay and S. Linn, Science, 1988, 240, 1302.

3. P. J. Brooks, DNA Repair (Amst), 2008, 7, 1168.

4. I. Kuraoka, C. Bender, A. Romieu, J. Cadet, et al., Proc. Natl. Acad. Sci. U. S. A., 2000, 97, 3832.

5. C. Marietta and P. J. Brooks, EMBO Rep., 2007, 8, 388.

6. P. J. Brooks, D. S. Wise, D. A. Berry, J. V. Kosmoski, et al., J. Biol. Chem., 2000, 275, 22355.

7. M. D'Errico, E. Parlanti, M. Teson, B. M. de Jesus, et al., Embo J., 2006, 25, 4305.

8. M. D'Errico, E. Parlanti, M. Teson, P. Degan, et al., Oncogene, 2007, 26, 4336.

9. G. Kirkali, N. C. de Souza-Pinto, P. Jaruga, V. A. Bohr, et al., DNA Repair (Amst), 2009, 8, 274.

10. J. Wang, C. L. Clauson, P. D. Robbins, L. J. Niedernhofer, et al., Aging Cell, 2012, 11, 714.

11. C. Chatgilialoglu, C. Ferreri, N. E. Geacintov, M. G. Krokidis, et al., Cells, 2019, 8.

12. A. Luch, Exs, 2009, 99, 151.

13. S. Amin, D. Desai, W. Dai, R. G. Harvey, et al., Carcinogenesis, 1995, 16, 2813.

14. S. Amin, J. Krzeminski, A. Rivenson, C. Kurtzke, et al., Carcinogenesis, 1995, 16, 1971.

15. A. K. Prahalad, J. A. Ross, G. B. Nelson, B. C. Roop, et al., Carcinogenesis, 1997, 18, 1955.

16. E. L. Cavalieri, S. Higginbotham, N. V. RamaKrishna, P. D. Devanesan, et al., Carcinogenesis, 1991, 12, 1939.

17. S. M. Zhang, K. M. Chen, C. Aliaga, Y. W. Sun, et al., Chem. Res. Toxicol., 2011, 24, 1297.

18. K. M. Li, M. George, M. L. Gross, C. H. Lin, et al., Chem. Res. Toxicol., 1999, 12, 778.

19. K. M. Li, J. Byun, M. L. Gross, D. Zamzow, et al., Chem. Res. Toxicol., 1999, 12, 749.

20. H. Yagi, H. Frank, A. Seidel and D. M. Jerina, Chem. Res. Toxicol., 2008, 21, 2379.

21. K. Kropachev, M. Kolbanovskiy, Z. Liu, Y. Cai, et al., Chem. Res. Toxicol., 2013, 26, 783.

22. V. S. Sidorenko, J. E. Yeo, R. R. Bonala, F. Johnson, et al., Nucleic Acids Res., 2012, 40, 2494. 
23. M. Lukin, T. Zaliznyak, F. Johnson and C. de los Santos, Nucleic Acids Res., 2012, 40, 2759.

24. T. Zaliznyak, R. Bonala, F. Johnson and C. de Los Santos, Chem. Res. Toxicol., 2006, 19, 745.

25. X. S. Cui, L. C. Eriksson and L. Moller, Mutat. Res., 1999, 442, 9.

26. C. A. Bieler, M. G. Cornelius, M. Stiborova, V. M. Arlt, et al., Carcinogenesis, 2007, 28, 1117.

27. H. Mao, Z. Deng, F. Wang, T. M. Harris, et al., Biochemistry, 1998, 37, 4374.

28. R. S. Cole, Biochim. Biophys. Acta., 1971, 254, 30.

29. B. H. Johnston and J. E. Hearst, Biochemistry, 1981, 20, 739.

30. G. D. Cimino, H. B. Gamper, S. T. Isaacs and J. E. Hearst, Annu. Rev. Biochem., 1985, 54, 1151.

31. K. W. Kohn, C. L. Spears and P. Doty, J. Mol. Biol., 1966, 19, 266.

32. F. Coste, J. M. Malinge, L. Serre, W. Shepard, et al., Nucleic Acids Res., 1999, 27, 1837.

33. M. Tomasz, Chem. Biol., 1995, 2, 575.

34. I. D. Kozekov, L. V. Nechev, M. S. Moseley, C. M. Harris, et al., J. Am. Chem. Soc., 2003, 125, 50.

35. S. Barker, M. Weinfeld and D. Murray, Mutat. Res., 2005, 589, 111.

36. J. Grillari, H. Katinger and R. Voglauer, Nucleic Acids Res., 2007, 35, 7566.

37. W. P. Vermeij, J. H. Hoeijmakers and J. Pothof, Curr. Opin. Genet. Dev., 2014, 26C, 124.

38. A. Sancar, L. A. Lindsey-Boltz, K. Unsal-Kacmaz and S. Linn, Annu. Rev. Biochem., 2004, 73, 39.

39. L. Cipak, N. Watanabe and T. Bessho, Nat. Struct. Mol. Biol., 2006, 13, 729.

40. H. E. Krokan and M. Bjoras, Cold Spring Harb. Perspect. Biol., 2013, 5, a012583.

41. A. A. Ischenko and M. K. Saparbaev, Nature, 2002, 415, 183.

42. S. Klimasauskas, S. Kumar, R. J. Roberts and X. Cheng, Cell, 1994, 76, 357.

43. J. T. Stivers, Prog. Nucleic Acid Res. Mol. Biol., 2004, 77, 37.

44. K. Hitomi, S. Iwai and J. A. Tainer, DNA Repair (Amst), 2007, 6, 410.

45. S. Boiteux, M. Bichara, R. P. Fuchs and J. Laval, Carcinogenesis, 1989, 10, 1905.

46. D. G. Vassylyev, T. Kashiwagi, Y. Mikami, M. Ariyoshi, et al., Cell, 1995, 83, 773.

47. S. Couve-Privat, G. Mace, F. Rosselli and M. K. Saparbaev, Nucleic Acids Res., 2007, 35, 5672.

48. V. Vartanian, I. G. Minko, S. Chawanthayatham, P. A. Egner, et al., Proc. Natl. Acad. Sci. U. S. A., 2017, 114, 4207.

49. F. Coste, M. Ober, Y. V. Le Bihan, M. A. Izquierdo, et al., Chem. Biol., 2008, 15, 706.

50. P. L. McKibbin, A. M. Fleming, M. A. Towheed, B. Van Houten, et al., J. Am. Chem. Soc., 2013, 135, 13851.

51. E. A. Mullins, R. Shi, Z. D. Parsons, P. K. Yuen, et al., Nature, 2015, 527, 254.

52. E. A. Mullins, R. Shi, L. A. Kotsch and B. F. Eichman, PLoS One, 2015, 10, e0127733.

53. E. A. Mullins, G. M. Warren, N. P. Bradley and B. F. Eichman, Proc. Natl. Acad .Sci. U. S. A., 2017, 114, 4400.

54. I. Alseth, T. Rognes, T. Lindbäck, I. Solberg, et al., Mol Microbiol, 2006, 59, 1602.

55. R. Shi, E. A. Mullins, X. X. Shen, K. T. Lay, et al., Embo j, 2018, 37, 63.

56. E. A. Mullins, R. Shi and B. F. Eichman, Nat. Chem. Biol., 2017, 13, 1002. 
57. H. Xu, W. Huang, Q. L. He, Z. X. Zhao, et al., Angew. Chem. Int. Ed. Engl., 2012, 51, 10532.

58. E. A. Mullins, A. A. Rodriguez, N. P. Bradley and B. F. Eichman, Trends Biochem. Sci., 2019, 44, 765.

59. S. Wang, K. Liu, L. Xiao, L. Yang, et al., Nucleic Acids Res., 2016, 44, 187.

60. S. Cheng, A. Sancar and J. E. Hearst, Nucleic Acids Res., 1991, 19, 657.

61. D. M. Noll, T. M. Mason and P. S. Miller, Chem. Rev., 2006, 106, 277.

62. Y. Huang and L. Li, Transl. Cancer Res., 2013, 2, 144.

63. D. Klein Douwel, R. A. Boonen, D. T. Long, A. A. Szypowska, et al., Mol. Cell, 2014, 54, 460.

64. M. R. Hodskinson, J. Silhan, G. P. Crossan, J. I. Garaycoechea, et al., Mol. Cell, 2014, $54,472$.

65. S. Couve, G. Mace-Aime, F. Rosselli and M. K. Saparbaev, J. Biol. Chem., 2009, 284, 11963.

66. M. Liu, S. Doublie and S. S. Wallace, Mutat. Res., 2013, 743-744, 4.

67. C. G. Neurauter, L. Luna and M. Bjoras, DNA Repair (Amst), 2012, 11, 401.

68. M. L. Hegde, P. M. Hegde, L. J. Bellot, S. M. Mandal, et al., Proc. Natl. Acad. Sci. U. S. A., 2013, 110, E3090.

69. M. Raschle, P. Knipsheer, M. Enoiu, T. Angelov, et al., Cell, 2008, 134, 969.

70. J. Zhang, J. M. Dewar, M. Budzowska, A. Motnenko, et al., Nat. Struct. Mol. Biol., 2015, 22, 242.

71. J. Huang, S. Liu, M. A. Bellani, A. K. Thazhathveetil, et al., Mol. Cell, 2013, 52, 434.

72. J. Zhang and J. C. Walter, DNA Repair (Amst), 2014, 19, 135.

73. D. R. Semlow, J. Zhang, M. Budzowska, A. C. Drohat, et al., Cell, 2016, 167, 498.

74. P. R. Martin, S. Couve, C. Zutterling, M. S. Albelazi, et al., Sci. Rep., 2017, 7, 17438.

75. V. Rolseth, S. Z. Krokeide, D. Kunke, C. G. Neurauter, et al., Biochim. Biophys. Acta, 2013, 1833, 1157.

76. A. Kothandapani, V. S. Dangeti, A. R. Brown, L. A. Banze, et al., J. Biol. Chem., 2011, 286, 14564.

77. A. Sawant, A. M. Floyd, M. Dangeti, W. Lei, et al., DNA Repair (Amst), 2017, 51, 46.

78. A. Kothandapani and S. M. Patrick, Mutat. Res., 2013, 743-744, 44.

79. M. L. Dodson, M. L. Michaels and R. S. Lloyd, J. Biol. Chem., 1994, 269, 32709.

80. M. L. Dodson and R. S. Lloyd, Free Radic. Biol. Med., 2002, 32, 678.

81. L. Gros, M. K. Saparbaev and J. Laval, Oncogene, 2002, 21, 8905.

82. H. E. Krokan, R. Standal and G. Slupphaug, Biochem. J., 1997, 325 ( Pt 1), 1.

83. A. L. Jacobs and P. Schar, Chromosoma, 2012, 121, 1.

84. D. M. Wilson III and D. Barsky, Mutat. Res., 2001, 485, 283.

85. B. Demple and J.-S. Sung, DNA Repair (Amst), 2005, 4, 1442.

86. H. Ide, K. Tedzuka, H. Shimzu, Y. Kimura, et al., Biochemistry, 1994, 33, 7842.

87. A. B. Guliaev, B. Hang and B. Singer, Nucleic Acids Res., 2004, 32, 2844.

88. S. Daviet, S. Couve-Privat, L. Gros, K. Shinozuka, et al., DNA Repair (Amst), 2007, 6, 8.

89. A. A. Ishchenko, E. Deprez, A. Maksimenko, J. C. Brochon, et al., Proc. Natl. Acad. Sci.

U. S. A., 2006, 103, 2564.

90. C. D. Mol, C. F. Kuo, M. M. Thayer, R. P. Cunningham, et al., Nature, 1995, 374, 381.

91. D. J. Hosfield, Y. Guan, B. J. Haas, R. P. Cunningham, et al., Cell, 1999, 98, 397.

92. C. D. Mol, T. Izumi, S. Mitra and J. A. Tainer, Nature, 2000, 403, 451.

93. B. Demple and L. Harrison, Annu. Rev. Biochem., 1994, 63, 915. 
94. G. Barzilay and I. D. Hickson, Bioessays, 1995, 17, 713.

95. H. E. Krokan, H. Nilsen, F. Skorpen, M. Otterlei, et al., FEBS Lett., 2000, 476, 73.

96. D. M. Wilson, 3rd, J. Mol. Biol., 2003, 330, 1027.

97. K. M. Chou and Y. C. Cheng, Nature, 2002, 415, 655.

98. J. L. Parsons, Dianova, II and G. L. Dianov, Nucleic Acids Res., 2005, 33, 2204.

99. L. Gros, A. A. Ishchenko, H. Ide, R. H. Elder, et al., Nucleic Acids Res., 2004, $32,73$.

100. P. Prorok, D. Alili, C. Saint-Pierre, D. Gasparutto, et al., Proc. Natl. Acad. Sci. U. S. A., 2013, 110, E3695.

101. P. Burkovics, V. Szukacsov, I. Unk and L. Haracska, Nucleic Acids Res., 2006, 34, 2508.

102. B. Joldybayeva, P. Prorok, I. R. Grin, D. O. Zharkov, et al., PLoS One, 2014, 9, e92963.

103. M. Redrejo-Rodriguez, A. Vigouroux, A. Mursalimov, I. Grin, et al., Biochimie, 2016, 128-129, 20.

104. S. Abeldenov, I. Talhaoui, D. O. Zharkov, A. A. Ishchenko, et al., DNA Repair (Amst), 2015, 33, 1.

105. M. Shiraishi, S. Ishino, T. Yamagami, Y. Egashira, et al., Nucleic Acids Res., 2015, 43, 2853.

106. M. Shiraishi and S. Iwai, J. Bacteriol., 2020, 202.

107. M. Shiraishi, S. Ishino, I. Cann and Y. Ishino, Biosci. Biotechnol. Biochem., 2017, 81, 931.

108. C. D. Mol, D. J. Hosfield and J. A. Tainer, Mutat. Res., 2000, 460, 211.

109. J. P. Erzberger and D. M. Wilson, 3rd, J. Mol. Biol., 1999, 290, 447.

110. B. D. Freudenthal, W. A. Beard, M. J. Cuneo, N. S. Dyrkheeva, et al., Nat. Struct. Mol. Biol., 2015, 22, 924.

111. P. T. Beernink, B. W. Segelke, M. Z. Hadi, J. P. Erzberger, et al., J. Mol. Biol., 2001, 307, 1023.

112. E. D. Garcin, D. J. Hosfield, S. A. Desai, B. J. Haas, et al., Nat. Struct. Mol. Biol., 2008, 15, 515.

113. I. Ivanov, J. A. Tainer and J. A. McCammon, Proc. Natl. Acad. Sci. U. S. A., 2007, 104, 1465.

114. S. E. Tsutakawa, D. S. Shin, C. D. Mol, T. Izumi, et al., J. Biol. Chem., 2013, 288, 8445.

115. A. Mazouzi, A. Vigouroux, B. Aikeshev, P. J. Brooks, et al., Proc. Natl. Acad. Sci. U. S. A., 2013, 110, E3071.

116. S. T. Mundle, M. H. Fattal, L. F. Melo, J. D. Coriolan, et al., DNA Repair (Amst), 2004, 3, 1447.

117. S. T. Mundle, J. C. Delaney, J. M. Essigmann and P. R. Strauss, Biochemistry, 2009, 48, 19.

118. M. M. Aboelnga and S. D. Wetmore, J. Am. Chem. Soc., 2019, 141, 8646.

119. I. V. Alekseeva, A. S. Bakman, Y. N. Vorobjev, O. S. Fedorova, et al., J. Phys. Chem. B, 2019, 123, 9546.

120. W. C. Kim, B. R. Berquist, M. Chohan, C. Uy, et al., J. Mol. Biol., 2011, 411, 960.

121. D. M. Wilson, 3rd, M. Takeshita, A. P. Grollman and B. Demple, J. Biol. Chem., 1995, 270, 16002.

122. G. Golan, A. A. Ishchenko, B. Khassenov, G. Shoham, et al., Mutat. Res., 2010, 685, 70.

123. A. Gelin, M. Redrejo-Rodriguez, J. Laval, O. S. Fedorova, et al., PLoS One, 2010, 5, e12241. 
124. J. Willis, Y. Patel, B. L. Lentz and S. Yan, Proc. Natl. Acad. Sci. U. S. A., 2013, 110, 10592.

125. Y. Lin, L. Bai, S. Cupello, M. A. Hossain, et al., Nucleic Acids Res., 2018, 46, 2479.

126. Y. Lin, J. Raj, J. Li, A. Ha, et al., Nucleic Acids Res., 2019, doi: 10.1093/nar/gkz1175.

127. J. R. Lakowicz, Principles of Fluorescence Spectroscopy, Springer, Berlin., 2006.

128. L. Y. Kanazhevskaya, V. V. Koval, D. O. Zharkov, P. R. Strauss, et al., Biochemistry, 2010, 49, 6451.

129. N. A. Timofeyeva, V. V. Koval, D. G. Knorre, D. O. Zharkov, et al., J. Biomol. Struct. Dyn., 2009, 26, 637.

130. N. A. Timofeyeva, V. V. Koval, A. A. Ishchenko, M. K. Saparbaev, et al., PLoS One, 2011, 6, e24063.

131. N. A. Timofeyeva, V. V. Koval, A. A. Ishchenko, M. K. Saparbaev, et al., Biochemistry (Mosc), 2011, 76, 273.

132. A. D. Miroshnikova, A. A. Kuznetsova, N. A. Kuznetsov and O. S. Fedorova, Acta Naturae, 2016, 8, 103.

133. R. W. Sinkeldam, N. J. Greco and Y. Tor, Chem. Rev., 2010, 110, 2579.

134. L. M. Wilhelmsson, Q. Rev. Biophys., 2010, 43, 159.

135. N. A. Timofeyeva and O. S. Fedorova, Mol. Biosyst., 2016, 12, 3435.

136. L. Y. Kanazhevskaya, V. V. Koval, Y. N. Vorobjev and O. S. Fedorova, Biochemistry, 2012, 51, 1306.

137. L. Y. Kanazhevskaya, V. V. Koval, A. A. Lomzov and O. S. Fedorova, DNA Repair, 2014, 21, 43.

138. I. V. Alekseeva, A. T. Davletgildeeva, O. V. Arkova, N. A. Kuznetsov, et al., Biochimie, 2019, 163, 73.

139. E. S. Dyakonova, V. V. Koval, A. A. Lomzov, A. A. Ishchenko, et al., Biochimie, 2018, 152, 53.

140. E. S. Dyakonova, V. V. Koval, A. A. Ishchenko, M. K. Saparbaev, et al., Biochemistry (Mosc), 2012, 77, 1162.

141. A. D. Miroshnikova, A. A. Kuznetsova, Y. N. Vorobjev, N. A. Kuznetsov, et al., Mol. Biosyst., 2016, 12, 1527.

142. S. C. Brooks, S. Adhikary, E. H. Rubinson and B. F. Eichman, Biochim. Biophys. Acta, 2013, 1834, 247.

143. N. A. Kuznetsov and O. S. Fedorova, Biochemistry (Mosc), 2016, 81, 1136.

144. V. M. Marathias, B. Jerkovic and P. H. Bolton, Nucleic Acids Res., 1999, 27, 1854.

145. A. R. Dunn, N. M. Kad, S. R. Nelson, D. M. Warshaw, et al., Nucleic Acids Res., 2011, 39, 7487.

146. A. Prakash, S. Doublie and S. S. Wallace, Prog. Mol. Biol. Transl. Sci., 2012, 110, 71.

147. S. R. Nelson, A. R. Dunn, S. D. Kathe, D. M. Warshaw, et al., Proc. Natl. Acad. Sci. U. S. A., 2014, 111, E2091.

148. V. V. Koval, N. A. Kuznetsov, A. A. Ishchenko, M. K. Saparbaev, et al., Mutat. Res., 2010, 685, 3.

149. N. A. Kuznetsov, O. A. Kladova, A. A. Kuznetsova, A. A. Ishchenko, et al., J. Biol. Chem., 2015, 290, 14338.

150. N. A. Kuznetsov, C. Bergonzo, A. J. Campbell, H. Li, et al., Nucleic Acids Res., 2015, 43, 272.

151. A. J. Lee and S. S. Wallace, Radiat. Phys. Chem. Oxf. Engl. 1993, 2016, 128, 126.

152. A. J. Lee and S. S. Wallace, Free Radic. Biol. Med., 2017, 107, 170. 
153. O. A. Kladova, A. A. Kuznetsova, O. S. Fedorova and N. A. Kuznetsov, Genes (Basel), 2017, 8, 1.

154. A. A. Kuznetsova, D. A. lakovlev, I. V. Misovets, A. A. Ishchenko, et al., Mol. Biosyst., 2017, 13, 2638.

155. A. A. Kuznetsova, A. G. Matveeva, A. D. Milov, Y. N. Vorobjev, et al., Nucleic Acids Res., 2018, 46, 11454.

156. N. A. Kuznetsov and O. S. Fedorova, Adv. Exp. Biol. Med., 2020, in press.

157. C. Blanpain, M. Mohrin, P. A. Sotiropoulou and E. Passegue, Cell Stem Cell, 2011, 8, 16.

158. A. Burkle, FEBS J., 2005, 272, 4576.

159. I. Talhaoui, N. A. Lebedeva, G. Zarkovic, C. Saint-Pierre, et al., Nucleic Acids Res., 2016, 44, 9279.

160. E. A. Belousova, C. Ishchenko capital A and O. I. Lavrik, Sci. Rep., 2018, 8, 4176.

161. D. Munnur, E. Bartlett, P. Mikolcevic, I. T. Kirby, et al., Nucleic Acids Res., 2019, 47, 5658.

162. C. Beck, I. Robert, B. Reina-San-Martin, V. Schreiber, et al., Exp. Cell. Res., 2014, 329, 18.

163. M. O. Hottiger, Annu. Rev. Biochem., 2015, 84, 227.

164. M. Posavec Marjanovic, K. Crawford and I. Ahel, Semin. Cell Dev. Biol., 2017, 63, 102.

165. J. M. Rodriguez-Vargas, F. J. Oliver-Pozo and F. Dantzer, Oxid. Med. Cell Longev., 2019, 2019, 2641712.

166. R. Gupte, Z. Liu and W. L. Kraus, Genes Dev., 2017, 31, 101.

167. L. Palazzo, O. Leidecker, E. Prokhorova, H. Dauben, et al., Elife, 2018, 7.

168. M. O. Hottiger, P. O. Hassa, B. Luscher, H. Schuler, et al., Trends Biochem. Sci., 2010, 35, 208.

169. T. Minaga and E. Kun, J. Biol. Chem., 1983, 258, 5726.

170. R. Alvarez-Gonzalez and F. R. Althaus, Mutat. Res., 1989, 218, 67.

171. L. Davidovic, M. Vodenicharov, E. B. Affar and G. G. Poirier, Exp. Cell. Res., 2001, 268, 7.

172. B. A. Gibson and W. L. Kraus, Nat. Rev. Mol. Cell Biol., 2012, 13, 411.

173. F. G. Sousa, R. Matuo, D. G. Soares, A. E. Escargueil, et al., Carcinogenesis, 2012, 33, 1433.

174. S. Eustermann, W. F. Wu, M. F. Langelier, J. C. Yang, et al., Mol. Cell, 2015, 60, 742.

175. M. F. Langelier, J. L. Planck, S. Roy and J. M. Pascal, Science, 2012, 336, 728.

176. J. M. Dawicki-McKenna, M. F. Langelier, J. E. DeNizio, A. A. Riccio, et al., Mol. Cell, 2015, 60, 755.

177. J. D. Steffen, M. M. McCauley and J. M. Pascal, Nucleic Acids Res., 2016, 44, 9771.

178. W. M. Shieh, J. C. Ame, M. V. Wilson, Z. Q. Wang, et al., J. Biol. Chem., 1998, 273, 30069.

179. K. Martin-Hernandez, J. M. Rodriguez-Vargas, V. Schreiber and F. Dantzer, Semin. Cell Dev. Biol., 2017, 63, 92.

180. J. Menissier de Murcia, M. Ricoul, L. Tartier, C. Niedergang, et al., Embo J., 2003, 22, 2255.

181. G. J. Grundy, L. M. Polo, Z. Zeng, S. L. Rulten, et al., Nat. Commun., 2016, 7, 12404.

182. C. Boehler, L. R. Gauthier, O. Mortusewicz, D. S. Biard, et al., Proc. Natl. Acad. Sci. U. S. A., 2011, 108, 2783. 
183. C. Beck, C. Boehler, J. Guirouilh Barbat, M. E. Bonnet, et al., Nucleic Acids Res., 2014, 42, 5616.

184. H. Shirai, A. R. Poetsch, A. Gunji, D. Maeda, et al., Cell Death Dis., 2013, 4, e656.

185. J. M. Hinz, Y. Rodriguez and M. J. Smerdon, Proc. Natl. Acad. Sci. U. S. A., 2010, 107, 4646.

186. I. D. Odell, J. E. Barbour, D. L. Murphy, J. A. Della-Maria, et al., Mol. Cell. Biol., 2011, 31, 4623.

187. J. Abplanalp and M. O. Hottiger, Semin. Cell Dev. Biol., 2017, 63, 114.

188. F. Ciccarone, M. Zampieri and P. Caiafa, Semin. Cell Dev. Biol., 2017, 63, 123.

189. Y. Tanaka, K. Yoshihara, A. Itaya, T. Kamiya, et al., J. Biol. Chem., 1984, 259, 6579.

190. M. S. Satoh, G. G. Poirier and T. Lindahl, Biochemistry, 1994, 33, 7099.

191. S. W. Yu, H. Wang, M. F. Poitras, C. Coombs, et al., Science, 2002, 297, 259.

192. G. Zarkovic, E. A. Belousova, I. Talhaoui, C. Saint-Pierre, et al., Nucleic Acids Res., 2018, 46, 2417.

193. D. Munnur and I. Ahel, Febs J., 2017, 284, 4002.

194. A. A. Riccio, G. Cingolani and J. M. Pascal, Nucleic Acids Res., 2016, 44, 1691.

195. R. Anand, L. Ranjha, E. Cannavo and P. Cejka, Mol. Cell, 2016, 64, 940.

196. H. E. Bryant, E. Petermann, N. Schultz, A. S. Jemth, et al., Embo J., 2009, 28, 2601.

197. I. Lonskaya, V. N. Potaman, L. S. Shlyakhtenko, E. A. Oussatcheva, et al., J. Biol. Chem., 2005, 280, 17076.

198. A. Hakme, H. K. Wong, F. Dantzer and V. Schreiber, EMBO Rep., 2008, 9, 1094.

199. P. Bai, Mol. Cell, 2015, 58, 947.

200. X. Luo and W. L. Kraus, Genes Dev., 2012, 26, 417.

201. K. Leger, D. Bar, N. Savic, R. Santoro, et al., Nucleic Acids Res., 2014, 42, 5072.

202. K. Ouararhni, R. Hadj-Slimane, S. Ait-Si-Ali, P. Robin, et al., Genes Dev., 2006, 20, 3324.

203. E. Fouquerel, E. M. Goellner, Z. Yu, J. P. Gagne, et al., Cell Rep., 2014, 8, 1819.

204. M. Y. Kim, S. Mauro, N. Gevry, J. T. Lis, et al., Cell, 2004, 119, 803.

205. M. F. Langelier, A. A. Riccio and J. M. Pascal, Nucleic Acids Res., 2014, 42, 7762.

206. M. Audebert, B. Salles and P. Calsou, J. Biol. Chem., 2004, 279, 55117.

207. D. S. Kim, C. V. Camacho, A. Nagari, V. S. Malladi, et al., Mol. Cell, 2019, 75, 1270.

208. Q. Chen, M. A. Kassab, F. Dantzer and X. Yu, Nat. Commun., 2018, 9, 3233.

209. N. J. Clark, M. Kramer, U. M. Muthurajan and K. Luger, J. Biol. Chem., 2012, 287, 32430.

210. C. Thomas, Y. Ji, C. Wu, H. Datz, et al., Proc. Natl. Acad. Sci. U. S. A., 2019, 116, 9941.

211. M. Cohen-Armon, L. Visochek, D. Rozensal, A. Kalal, et al., Mol. Cell, 2007, 25, 297.

212. F. Berger, C. Lau and M. Ziegler, Proc. Natl. Acad. Sci. U. S. A., 2007, 104, 3765.

213. T. Guastafierro, B. Cecchinelli, M. Zampieri, A. Reale, et al., J. Biol. Chem., 2008, 283, 21873.

214. F. Ciccarone, E. Valentini, M. Zampieri and P. Caiafa, Oncotarget, 2015, 6, 24333.

215. S. Erener, M. Hesse, R. Kostadinova and M. O. Hottiger, Mol. Endocrinol., 2012, 26, 79.

216. C. Guetg and R. Santoro, Epigenetics, 2012, 7, 811.

217. M. Sajish and P. Schimmel, Nature, 2015, 519, 370.

218. T. M. Kauppinen, W. Y. Chan, S. W. Suh, A. K. Wiggins, et al., Proc. Natl. Acad. Sci. U. S. A., 2006, 103, 7136.

219. S. Zhang, Y. Lin, Y. S. Kim, M. P. Hande, et al., Cell Death Differ., 2007, 14, 1001. 
220. R. H. Wright, G. Castellano, J. Bonet, F. Le Dily, et al., Genes Dev., 2012, 26, 1972.

221. P. O. Hassa, S. S. Haenni, C. Buerki, N. I. Meier, et al., J. Biol. Chem., 2005, 280, 40450.

222. S. B. Rajamohan, V. B. Pillai, M. Gupta, N. R. Sundaresan, et al., Mol. Cell. Biol., 2009, 29, 4116.

223. O. Loseva, A. S. Jemth, H. E. Bryant, H. Schuler, et al., J. Biol. Chem., 2010, 285, 8054.

224. M. Van Meter, Z. Mao, V. Gorbunova and A. Seluanov, Cell Cycle, 2011, 10, 3153.

225. P. C. Hsu, R. K. Gopinath, Y. A. Hsueh and S. Y. Shieh, Oncogene, 2019, 38, 1166.

226. I. Kassner, A. Andersson, M. Fey, M. Tomas, et al., Open Biol., 2013, 3, 120173. 